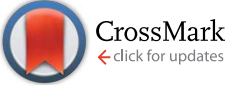

Cite this: RSC Adv., 2015, 5, 87139

\title{
Synthesis, structure and magnetic characterization of dinuclear copper(II) complexes bridged by bicompartmental phenolate $\dagger$
}

\author{
Salah S. Massoud, ${ }^{\text {aa }}$ Thomas Junk, ${ }^{a}$ Febee R. Louka, ${ }^{a}$ Radovan Herchel, ${ }^{b}$ \\ Zdeněk Trávníček, ${ }^{\text {bb }}$ Roland C. Fischer ${ }^{c}$ and Franz A. Mautner ${ }^{\star d}$
}

\begin{abstract}
The reaction of $\mathrm{Cu}(॥)$ salts with the bicompartmental 2,6-bis[bis(2-pyridylmethyl)aminomethyl]-4chlorophenol $\left(\mathrm{L}^{\mathrm{Cl}}-\mathrm{OH}\right)$ ligand afforded four new dinuclear bridged phenoxido $\mathrm{Cu}(I)$ complexes. Three

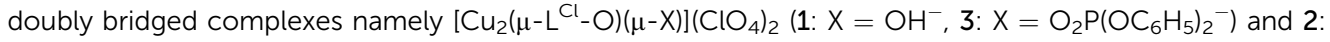
$\left[\mathrm{Cu}_{2}\left(\mu-\mathrm{L}^{\mathrm{Cl}}-\mathrm{O}\right)(\mu-\mathrm{pz})\left(\mathrm{ClO}_{4}\right)\right] \mathrm{ClO}_{4}$ (2) where $\mathrm{pz}=$ pyrazolyl anion, and one singly bridged-phenoxido, $\left[\mathrm{Cu}_{2}\left(\mu-\mathrm{L}^{\mathrm{Cl}}-\mathrm{O}\right)(\mathrm{dca})_{2}\right] \mathrm{PF}_{6} \cdot 2 \mathrm{CH}_{3} \mathrm{CN}\left(4 \cdot 2 \mathrm{CH}_{3} \mathrm{CN}\right)$ (dca = dicyanamide anion). A complex similar to 4 was also obtained with 2,6-bis[bis(2-pyridylmethyl)aminomethyl]-4-methylphenol $\left(\mathrm{L}^{\mathrm{Me}}-\mathrm{OH}\right), \quad\left[\mathrm{Cu}_{2}\left(\mu-\mathrm{L}^{\mathrm{Me}}\right.\right.$ O) $\left.(\mathrm{dca})_{2}\right] \mathrm{PF}_{6} \cdot 2 \mathrm{CH}_{3} \mathrm{CN}\left(5 \cdot 2 \mathrm{CH}_{3} \mathrm{CN}\right)$ where in both cases dca are acting as terminal monodentate ligands. The complexes were structurally characterized by various spectroscopic techniques (IR, UV-VIS and ESI-MS) and by single crystal crystallography. Magnetic susceptibility measurements at variable temperature revealed strong to very strong antiferromagnetic coupling (AF) in the doubly bridged complexes 1-3 and very weak AF interaction in the dicyanamido compounds 4 and 5 . The DFT calculations for the coupling constants, $J$ were in agreement with the experimentally observed behavior. The trend in magnetic properties was attributed to the strength of overlap between the orbitals $\left(d_{x^{2}-y^{2}} / d_{x^{2}-y^{2}}\right.$ vs. $d_{z^{2}} / d_{x^{2}-y^{2}}$ vs. $\left.d_{z^{2}} / d_{z^{2}}\right)$ resulting from trigonal bipyramidal (TBP) or square pyramidal (SP) geometries.
\end{abstract}

Received 20th September 2015

Accepted 7th October 2015

DOI: $10.1039 / c 5 r a 19358 c$

www.rsc.org/advances

\section{Introduction}

A variety of compartmental ligands based on phenolic compounds which possess two symmetrical and asymmetrical pendant chelating arms attached to the 2-and 6-positions of the phenol ring have been synthesized..$^{1-11}$ These ligands are known to accommodate two homo- or hetero-metallic $3 \mathrm{~d}$ metal ions and hence producing dinuclear metal complexes bridged by the

\footnotetext{
${ }^{a}$ Department of Chemistry, University of Louisiana at Lafayette, Lafayette, LA 70504, USA. E-mail: ssmassoud@louisiana.edu; Fax: +1-337-482-5676; Tel: +1-337-482-5672 ${ }^{b}$ Department of Inorganic Chemistry \& Regional Centre of Advanced Technologies and Materials, Faculty of Science, Palacký University, 17. listopadu 12, CZ-77146 Olomouc, Czech Republic. E-mail: zdenek.travnicek@upol.cz; Fax: +420-585-634954; Tel: +420-585-634-352

'Institut für Anorganische Chemische, Technische Universität Graz, Stremayrgasse 9/V, A-8010 Graz, Austria

${ }^{d}$ Institut für Physikalische and Theoretische Chemie, Technische Universität Graz, Stremayrgasse 9/II, A-8010, Graz, Austria. E-mail: mautner@tugraz.at; Fax: +43316-4873-8225; Tel: +43-316-4873-8234

$\dagger$ Electronic supplementary information (ESI) available: Fig. S1-S5 show the mass spectra of the complexes 1-5, respectively whereas Fig. S6-S10 are showing the corresponding packing plots for the crystal structures. Selected bond parameters of complexes 1-5 are summarized in Tables S1-S5, respectively. CCDC 1060469-1060473 contain the crystallographic data in CIF format for 1-5, respectively. For ESI and crystallographic data in CIF file or other electronic format see DOI: $10.1039 / \mathrm{c} 5 \mathrm{ra} 19358 \mathrm{c}$
}

deprotonated phenolic group and in some cases by one or two other groups such as acetate, benzoate or hydroxide ions..$^{4-25}$ In many of these compounds, the coordination environment around the central metal ions is "coordinatively unsaturated" and/or the metal ion(s) is coordinated to "weakly bound" ligand(s). ${ }^{1,2,4-6,10-13}$ This property made this class of compounds to serve as good candidates to mimic biological systems and as a consequence they have been extensively employed to elucidate the structural spectroscopic parameters and to mimic the mechanism of metalloenzymes in catecholase oxidases, $\mathrm{Mn}$ catalases, metallo- $\beta$-lactamases $(\mathrm{M} \beta \mathrm{L})^{7,13,26-30}$ and particularly in the hydrolytic systems. ${ }^{\mathbf{8} 21,31,32}$ These includes phosphodiester bonds of biomolecules such as DNA, purple acid phosphatases and $\mathrm{Zn}$ phosphesterases. . $^{\mathbf{8} 21,31-33}$

In addition to the advantages of the compartmental dinuclear metal(II) complexes which derived from phenolic compounds in enhancing our understanding for the role of metal ions in the active sides of metalloenzymes, the compounds could provide interesting magnetic properties as a result of the magnetic coupling between the two paramagnetic metal centers $\left(3 \mathrm{~d}^{7-9}\right)$ bridged via the phenoxido group. The close proximity between the bridged metal ions, which is generally within the range of 2.9-4.0 ̊ provide an excellent pathway for strong antiferromagnetic interaction between the two metallic centers. ${ }^{1,2,4,28,30,34,35}$ Also, the magnetic coupling between the two metal ions could be 


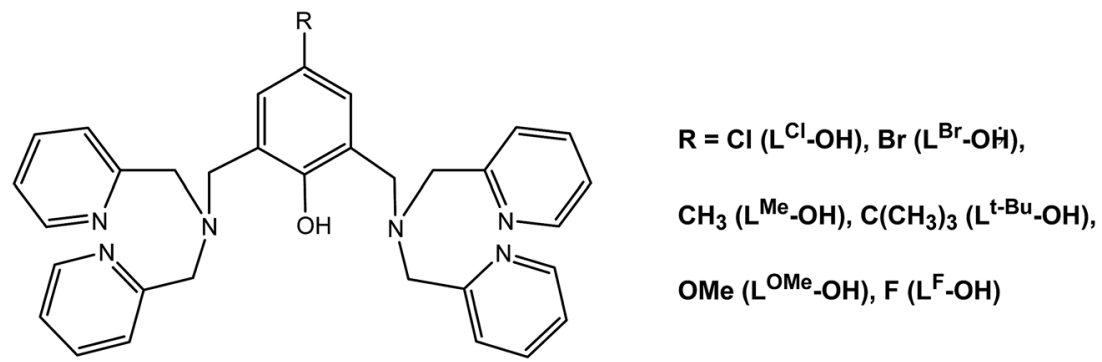

Chart 1 Structural formula of bis[bis(2-pyridylmethyl)aminomethyl]-4-substitutedphenol $\left(\mathrm{L}^{\mathrm{R}}-\mathrm{OH}\right)$.

enhanced by inserting another bridging ligand which can further propagate the magnetic coupling., $4,28,30,34,35$

Herein, we report a continuation of our previous studies on dinuclear metal(II) based phenolate ligands. ${ }^{\mathbf{1 , 2}}$ Our discussion will be limited on symmetrical tetra-methyl pyridyl compounds namely bis[bis(2-pyridylmethyl)aminomethyl]-4-chlorophenol $\left(\mathrm{L}^{\mathrm{Cl}}\right.$ $\mathrm{OH}$ and bis[bis(2-pyridylmethyl)aminomethyl]-4-methylphenol $\left(\mathrm{L}^{\mathrm{Me}}-\mathrm{OH}\right)$ which are illustrated in Chart 1 . We report the synthesis, structure and magnetic characterization of three doubly bridged copper(II)-phenoxido complexes with $\mathrm{OH}^{-}$, pyrazolyl anion $\left(\mathrm{pz}^{-}\right)$and diphenylphosphate, as well as two singly bridged complexes with dicyanamide ion $\mathrm{N}(\mathrm{CN})_{2}{ }^{-}$(dca).

\section{Results and discussion}

\section{Synthesis of the complexes}

The reaction of a methanolic solution of 2,6-bis[bis(2pyridylmethyl)aminomethyl]-4-chlorophenol $\left(\mathrm{L}^{\mathrm{Cl}}-\mathrm{OH}\right)$ with two equivalents of $\mathrm{Cu}\left(\mathrm{ClO}_{4}\right)_{2} \cdot 6 \mathrm{H}_{2} \mathrm{O}$ in the presence $\mathrm{Na}_{2} \mathrm{CO}_{3}$, pyrazole $(\mathrm{Hpz})$ and diphenyl phosphate afforded the dinuclear $\mathrm{Cu}(\mathrm{II})$ complexes $\left[\mathrm{Cu}_{2}\left(\mu-\mathrm{L}^{\mathrm{Cl}}-\mathrm{O}\right)\left(\mu_{2}-\mathrm{OH}\right)\right]\left(\mathrm{ClO}_{4}\right)_{2}(\mathbf{1}),\left[\mathrm{Cu}_{2}\left(\mu-\mathrm{L}^{\mathrm{Cl}} \mathrm{O}\right)-\right.$ $\left.(\mu-\mathrm{pz})\left(\mathrm{ClO}_{4}\right)\right] \mathrm{ClO}_{4}(2)$ and $\left[\mathrm{Cu}_{2}\left(\mu-\mathrm{L}^{\mathrm{Cl}}-\mathrm{O}\right)\left(\mu-\left(\mathrm{O}_{2} \mathrm{P}\left(\mathrm{OC}_{6} \mathrm{H}_{5}\right)_{2}\right)\right)\right]\left(\mathrm{ClO}_{4}\right)_{2}$ (3), respectively whereas the corresponding reactions of $\mathrm{Cu}\left(\mathrm{NO}_{3}\right)_{2} \cdot 3 \mathrm{H}_{2} \mathrm{O}$ and 2,6-bis[bis(2-pyridylmethyl)aminomethyl]4-chlorophenol $\quad\left(\mathrm{L}^{\mathrm{Cl}}-\mathrm{OH}\right)$ or 2,6-bis[bis(2-pyridylmethyl) aminomethyl]-4-methylphenol $\left(\mathrm{L}^{\mathrm{Me}}-\mathrm{OH}\right)$ with an aqueous solution of sodium dicyanamide (Nadca) resulted in the formation of $\left[\mathrm{Cu}_{2}\left(\mu-\mathrm{L}^{\mathrm{Cl}}-\mathrm{O}\right)(\mathrm{dca})_{2}\right] \mathrm{PF}_{6} \cdot 2 \mathrm{CH}_{3} \mathrm{CN}\left(\mathbf{4} \cdot 2 \mathrm{CH}_{3} \mathrm{CN}\right)$ and $\left[\mathrm{Cu}_{2}\left(\mu-\mathrm{L}^{\mathrm{Me}}-\mathrm{O}\right)-\right.$ (dca) $\left.)_{2}\right] \mathrm{PF}_{6} \cdot 2 \mathrm{CH}_{3} \mathrm{CN}\left(5 \cdot 2 \mathrm{CH}_{3} \mathrm{CN}\right)$, respectively. The complexes were obtained in moderate to high yield (60-90\%) in which the phenolic groups in all complexes and the pyrazine ligand in complex 2 were deprotonated. The isolated complexes were characterized by elemental microanalyses, molar conductivity, IR and UV-VIS spectroscopy, ESI-MS spectrometry, and single crystal X-ray crystallography. The magnetic properties of the complexes were determined at variable temperature. The molar conductivities of the complexes 1-3 $\left(\Lambda_{\mathrm{M}}=267-298 \Omega^{-1} \mathrm{~cm}^{2}\right.$ $\mathrm{mol}^{-1}$ ) as measured in $\mathrm{CH}_{3} \mathrm{CN}$ were consistent with $1: 2$ electrolyte, whereas values of 161 and $179 \Omega^{-1} \mathrm{~cm}^{2} \mathrm{~mol}^{-1}$ determined in complexes 4 and 5 are typical for $1: 1$ electrolytic behavior. The 1 : 2 electrolytic nature of complexes 1-3 is clearly obvious from their structural compositions which were also confirmed by the presence of extra bridges of mononegative anions $\left(\mathrm{OH}^{-}, \mathrm{pz}^{-}\right.$or $\left.\left(\mathrm{C}_{6} \mathrm{H}_{5} \mathrm{O}\right)_{2} \mathrm{PO}_{2}^{-}\right)$in the bridged-phenoxido complexes $\left[\mathrm{Cu}_{2}\left(\mu-\mathrm{L}^{\mathrm{Cl}}-\mathrm{O}\right)(\mu-\mathrm{OH})\right]\left(\mathrm{ClO}_{4}\right)_{2} \quad(\mathbf{1}),\left[\mathrm{Cu}_{2}\left(\mu-\mathrm{L}^{\mathrm{Cl}} \mathrm{O}\right)(\mu-\mathrm{pz})\right.$ $\left.\left(\mathrm{ClO}_{4}\right)\right] \mathrm{ClO}_{4}$ (2) and $\left[\mathrm{Cu}_{2}\left(\mu-\mathrm{L}^{\mathrm{Cl}}-\mathrm{O}\right)\left(\mu-\left(\mathrm{O}_{2} \mathrm{P}\left(\mathrm{OC}_{6} \mathrm{H}_{5}\right)_{2}\right)\right)\right]\left(\mathrm{ClO}_{4}\right)_{2}$ (3) (see X-ray section).

In the complexes 1-3, the two $\mathrm{Cu}(\mathrm{II})$ ions are doubly bridged by the phenoxido group and a hydroxido group in 1, pyrazolyl and diphenylphosphate anions in 2 and 3, respectively. Bridged phenoxido complexes similar to $\mathbf{1}$ have been previously obtained in similar class of ligands. ${ }^{5,28,36}$ Interestingly, although doubly-bridged mono(diphenylphosphato) complex 3 was isolated here, doubly-bridged bis(diphenylphosphato) complex was reported with $\mathrm{Co}(\mathrm{II}), \quad\left[\mathrm{Co}_{2}\left(\mu-\mathrm{L}^{t-\mathrm{Bu}}-\mathrm{O}\right)\left(\mu-\left(\mathrm{O}_{2} \mathrm{P}\left(\mathrm{OC}_{6} \mathrm{H}_{5}\right)_{2}\right)\right)\right]$ $\left(\mathrm{ClO}_{4}\right)_{2} \cdot{ }^{37}$ Attempts made to synthesize the corresponding bis(4-nitrophenylphosphato) (BNP) of 3 were unsuccessful, most likely due to the rapid hydrolysis of BNP under the reaction conditions. Similarly attempts made to synthesize the bridgedazido or bridged-dicyanamido complexes were completely failed and instead, only the bridged-phenoxido complexes $\left[\mathrm{Cu}_{2}\left(\mathrm{~L}^{\mathrm{Me}} \mathrm{O}\right)\right.$ $\left.\left(\mathrm{N}_{3}\right)_{2}\right] \mathrm{ClO}_{4}$ (ref. 2) and $\left[\mathrm{Cu}_{2}\left(\mu-\mathrm{L}^{\mathrm{R}}-\mathrm{O}\right)(\mathrm{dca})_{2}\right] \mathrm{PF}_{6} \cdot 2 \mathrm{CH}_{3} \mathrm{CN}(4, \mathrm{R}=$ $\mathrm{Cl} ; \mathbf{5}, \mathrm{R}=\mathrm{Me}$ ) were produced in which $\mathrm{N}_{3}{ }^{-}$and dca were acting as simple monodentate ligands.

\section{IR spectra of the complexes}

The IR spectra of the perchlorate complexes 1-3 displayed the $\nu(\mathrm{Cl}-\mathrm{O})$ band as broad strong absorption around $1092 \mathrm{~cm}^{-1}$ as in complex 1 or split of the band into two or three bands over the range 1090-1120 $\mathrm{cm}^{-1}$ as observed in complexes 2 and 3 , respectively. The broadening or split of the $\nu(\mathrm{Cl}-\mathrm{O})$ band is attributed to the reduction of the $\mathrm{ClO}_{4}{ }^{-}$ion symmetry from $T_{\mathrm{d}}$ to $\mathrm{C}_{3 \nu}$ or $\mathrm{C}_{2 \nu}$ symmetries as a result of the involvement of the counter $\mathrm{ClO}_{4}{ }^{-}$ion in $\mathrm{H}$-bonding with the ligand or its presence in a distorted location. The dicyanamido hexafluorophosphate complexes $\mathbf{4}$ and $\mathbf{5}$ displayed strong absorption band around $840 \mathrm{~cm}^{-1}$, due to $\nu(\mathrm{P}-\mathrm{F})$. The latter two complexes showed two series of bands: a strong absorption in the $2160-2180 \mathrm{~cm}^{-1}$ region corresponding to $\nu_{\mathrm{s}}(\mathrm{C} \equiv \mathrm{N})$ and two weak to medium absorption bands in the $2220-2290 \mathrm{~cm}^{-1}$ region corresponding to $\nu_{\text {as }}(\mathrm{C} \equiv \mathrm{N})$, and $\nu_{\mathrm{s}}+\nu_{\text {as }}(\mathrm{C} \equiv \mathrm{N})^{38}$ and these were in agreement with those observed in other monodentate dicyanamido complexes. $^{39}$ The frequencies of these peaks were shifted to higher values compared to the corresponding peaks observed in the free dca in its sodium salt $\left(2129,2232\right.$ and $2286 \mathrm{~cm}^{-1}$ ) indicating its coordination. The bridged hydroxido complex $\mathbf{1}$, revealed the stretching frequency $\nu(\mathrm{O}-\mathrm{H})$ band at $3429 \mathrm{~cm}^{-1}$. The complexes also displayed a series of weak to medium 
intensity bands over the $1610-1440 \mathrm{~cm}^{-1}$ region which are characteristic of the bis(pyridyl) moieties ${ }^{40}$ and $\mathrm{C}=\mathrm{C}$ of the phenolate group.

\section{Electronic spectra of complexes}

The acetonitrile spectra of copper complexes under investigation revealed the presence of two broad maxima over the wavelength regions $440-480$ and $700-810 \mathrm{~nm}$. The former band in the 440-480 $\mathrm{nm}$ region observed in complexes 2-4, most likely corresponds to L $\rightarrow$ M CT transition between the bridged phenoxido and copper ions. The second observed broad band (710-810 $\mathrm{nm}$ region, $\varepsilon=140-200 \mathrm{M}^{-1} \mathrm{~cm}^{-1}$ ) is characteristic for $\mathrm{Cu}(\mathrm{II}) \mathrm{d}-\mathrm{d}$ transition in five-coordinate complexes. The long wavelength position of this band suggests a distorted square pyramidal (SP) stereochemistry around the central $\mathrm{Cu}$ (II) ions. It is well established that five-coordinate $\mathrm{SP} \mathrm{Cu}(\mathrm{II})$ complexes are most likely producing a broad band in the visible region which occasionally may or may not be associated with a low-energy shoulder at $\lambda>800 \mathrm{~nm}$. This band results from $\mathrm{d}_{x z}, \mathrm{~d}_{y z} \rightarrow$ $\mathrm{d}_{x^{2}-y^{2}}$ transition. ${ }^{\mathbf{4 1 , 4 2}}$ Similar UV-Vis spectral features have been previously reported in related $\mu$-phenoxido dicopper(II) complexes. ${ }^{\mathbf{1 , 2 , 2 8 , 4 3}}$ Thus, based on the above criterion in $\mathrm{CH}_{3} \mathrm{CN}$ solution, the complexes under investigation adopt distorted SP geometry around the central $\mathrm{Cu}(\mathrm{II})$ atoms. This assignment in solution was in agreement with those obtained by single crystal X-ray crystallography.

\section{Mass spectra of complexes}

ESI-MS spectra of the chlorophenolate complexes 1-4 and the methylphenolate complex $\mathbf{5}$, recorded in acetonitrile and all are shown in Fig. S1-S5 (ESI $\dagger$ ), displayed some general characteristic features which provide qualitative information about their compositions. The mass spectra of the complexes 1, 3 and 4 showed two major peaks at $m / z=835.059 \pm 0.001$ (this was observed at $m / z=821.020$ for complex 2) and 767.071 \pm 0.002 . The former peak may result from the formation of a species with additional coordination of $\mathrm{OH}^{-} / \mathrm{H}_{2} \mathrm{O} / \mathrm{MeCN}$ to the $\mathrm{Cu}$ (II) centers such as $\left[\mathrm{Cu}_{2}\left(\mathrm{~L}^{\mathrm{Cl}} \mathrm{O}\right)(\mathrm{OH})\left(\mathrm{H}_{2} \mathrm{O}\right)(\mathrm{MeCN})_{3}\right]^{2+}($ calcd $m / z=835.158)$ in complexes 1, 3 and 4, whereas the corresponding peak observed in complex $2(m / z=821.020)$ could be assigned to $\left[\mathrm{Cu}_{2}\left(\mathrm{~L}^{\mathrm{Cl}} \mathrm{O}\right)\right.$ $\left.(\mathrm{pz})\left(\mathrm{H}_{2} \mathrm{O}\right)(\mathrm{MeCN})\right]^{2+}$ (calcd $\left.m / z=821.317\right)$. The second major peak which was detected in complexes 1-4 at $767.071 \pm$ 0.002 could be attributed to the fragments $\left\{\left[\mathrm{Cu}_{2}\left(\mathrm{~L}^{\mathrm{Cl}} \mathrm{O}\right)\right.\right.$ $\left.\left.\left(\mathrm{H}_{2} \mathrm{O}\right)\right]^{3+}+2 \mathrm{Cl}^{-}+\mathrm{H}^{+}\right\}^{2+}$ (calcd $\left.m / z=767.094\right)$ in complexes 1-3 and $\left\{\left[\mathrm{Cu}_{2}\left(\mathrm{~L}^{\mathrm{Cl}} \mathrm{O}\right)(\mathrm{OH})\left(\mathrm{H}_{2} \mathrm{O}\right)_{3}\right]^{2+}+\mathrm{F}^{-}+\mathrm{H}^{+}\right\}^{2+}($ calcd $m / z=767.031)$ in complex 4. Similar peaks were observed in complex 5 at $\mathrm{m} / z=$ 813.113 and 747.125 corresponding to the species $\left[\mathrm{Cu}_{2}\left(\mathrm{~L}^{\mathrm{Me}} \mathrm{O}\right)\right.$ $\left.(\mathrm{OH})_{2}(\mathrm{MeCN})_{3}\right]^{+}$(calcd $\left.m / z=813.917\right)$ and $\left\{\left[\mathrm{Cu}_{2}\left(\mathrm{~L}^{\mathrm{Me}} \mathrm{O}\right)-\right.\right.$ $\left.\left.(\mathrm{OH})\left(\mathrm{H}_{2} \mathrm{O}\right)_{3}\right]^{2+}+\mathrm{F}^{-}\right\}^{+}$(calcd $m / z=746.798$ ), respectively. The spectra revealed a distinct peak at $m / z=361.035 \pm 0.001$ for complexes 1-4 and at 351.063 for complex 5 due to doubly charged ions. These were assigned to the fragment $\left[\mathrm{Cu}_{2}\left(\mathrm{~L}^{\mathrm{R}} \mathrm{O}\right)\right.$ $\left.\left(\mathrm{H}_{2} \mathrm{O}\right)(\mathrm{HCN})\right]^{3+}($ calcd $m / z=361.103$ for $\mathrm{R}=\mathrm{Cl}$ in complexes 1-4 and $m / z=350.894$ for $\mathrm{R}=$ Me in complex 5). In addition to these peaks, the perchlorate complexes 1-3, and the hexafluorophosphate complexes $\mathbf{4}$ and $\mathbf{5}$ displayed an $\mathrm{m} / \mathrm{z}$ peak at
$98.949(100 \%)$ and $144.949(100 \%)$ attributable to the $\mathrm{ClO}_{4}{ }^{-}$ (calcd $m / z$ 99.451) and $\mathrm{PF}_{6}{ }^{-}$(calcd $m / z$ 144.642) ions, respectively.

Species with additional coordination such as those observed in the above complexes when MeCN was used as a solvent in measuring the mass spectra, have been recently reported in some dinuclear metal(II) complexes based phenolate. ${ }^{2,44}$

\section{Crystal structures of the complexes}

$\left[\mathrm{Cu}_{2}\left(\mu-\mathrm{L}^{\mathrm{Cl}} \mathrm{O}\right)(\mu-\mathrm{OH})\right]\left(\mathrm{ClO}_{4}\right)_{2}(\mathbf{1})$. The molecular structure of $\mathbf{1}$ consists of dinuclear $\left[\mathrm{Cu}_{2}\left(\mathrm{~L}^{\mathrm{Cl}} \mathrm{O}\right)(\mathrm{OH})\right]^{2+}$ complex cations and $\mathrm{ClO}_{4}{ }^{-}$counter ions. A perspective view of the complex cation together with partial atom numbering schemes is given in Fig. 1, and selected bond parameters are summarized in Table $\mathrm{S} 1$ (ESI $\dagger$ ). Each $\mathrm{Cu}$ (II) center within the dinuclear complex cation is penta-coordinated by three $\mathrm{N}$-donor atoms of one bispyridylamino group, the bridging $\mathrm{O}(1)$ atom of central 4-chlorophenolate moiety and $\mathrm{O}(10)$ oxygen atom of bridging hydroxy group. Both $\mathrm{CuN}_{3} \mathrm{O}_{2}$ chromophores adopt distorted SP geometry [ $\tau$-values: 0.15 and 0.14 , for $\mathrm{Cu}(1)$ and $\mathrm{Cu}(2)$, respectively] ${ }^{45}$ with $\mathrm{N}(3)$ and $\mathrm{O}(1)$ atoms in apical sites $[\mathrm{Cu}(1)-\mathrm{N}(3)=2.205(5)$, $\mathrm{Cu}(2)-\mathrm{O}(1)=2.200(4) \AA]$. The basal $\mathrm{Cu}-\mathrm{N} / \mathrm{O}$ bond distances are in the range from $1.932(3)$ to $2.044(5) \AA$. The $\mathrm{Cu}(1) \cdots \mathrm{Cu}(2)$ intradimeric distance is 3.0297(13) $\AA$, and the shortest inter-dimer metal-metal separation is 7.166(2) A. The $\mathrm{Cu}(1)-\mathrm{O}(1)-\mathrm{Cu}(2)$, $\mathrm{Cu}(1)-\mathrm{O}(10)-\mathrm{Cu}(2), \mathrm{O}(1)-\mathrm{Cu}(1)-\mathrm{O}(10)$ and $\mathrm{O}(1)-\mathrm{Cu}(2)-\mathrm{O}(10)$ bond angles are 93.36(15), 103.29(18), 84.49(15) and $78.27(14)^{\circ}$, respectively. $\mathrm{Cu}(2)$ forms an additional semi-coordinative bond to $\mathrm{O}(6 \mathrm{~A})$ atom of partially disordered perchlorato anion $[\mathrm{Cu}(2)-\mathrm{O}(6 \mathrm{~A})$ $(x, 1 / 2-y, 1 / 2+z)=2.719(8) \AA]$ (Fig. S6†).

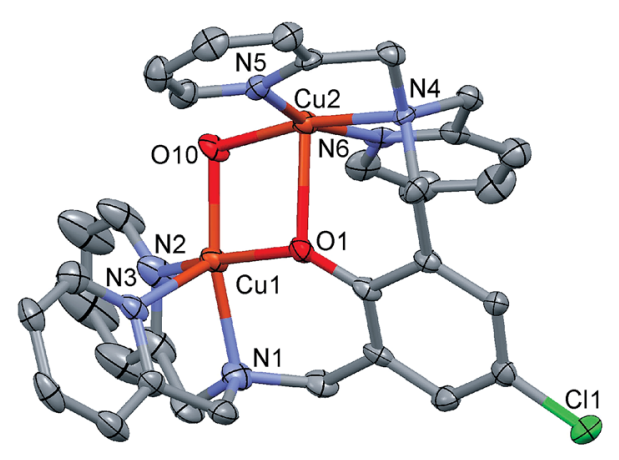

Fig. 1 Perspective view and atom numbering scheme of the complex cation, $\left[\mathrm{Cu}_{2}\left(\mathrm{~L}^{\mathrm{Cl} O}\right)(\mu-\mathrm{OH})\right]^{2+}$ of complex 1 . $\mathrm{H}$-atoms are omitted for clarity.

$\left[\mathrm{Cu}_{2}\left(\boldsymbol{\mu}-\mathrm{L}^{\mathrm{Cl}} \mathrm{O}\right)(\boldsymbol{\mu}-\mathbf{p z})\left(\mathrm{ClO}_{4}\right)\right] \mathbf{C l O}_{\mathbf{4}}$ (2). The molecular structure of 2 consists of dinuclear $\left[\mathrm{Cu}_{2}\left(\mathrm{~L}^{\mathrm{Cl}} \mathrm{O}\right)\left(\mathrm{C}_{3} \mathrm{H}_{3} \mathrm{~N}_{2}\right)\left(\mathrm{ClO}_{4}\right)\right]^{+}$complex cations and $\mathrm{ClO}_{4}{ }^{-}$counter ions. A perspective view of the complex cations together with partial atom numbering scheme is given in Fig. 2, and selected bond parameters are summarized in Table $\mathrm{S} 2 . \dagger \mathrm{Cu}(1)$ has a $4+1+1$ geometry formed by three $\mathrm{N}$ donor atoms of one bis-pyridylamino group, N(7) of a bridging 


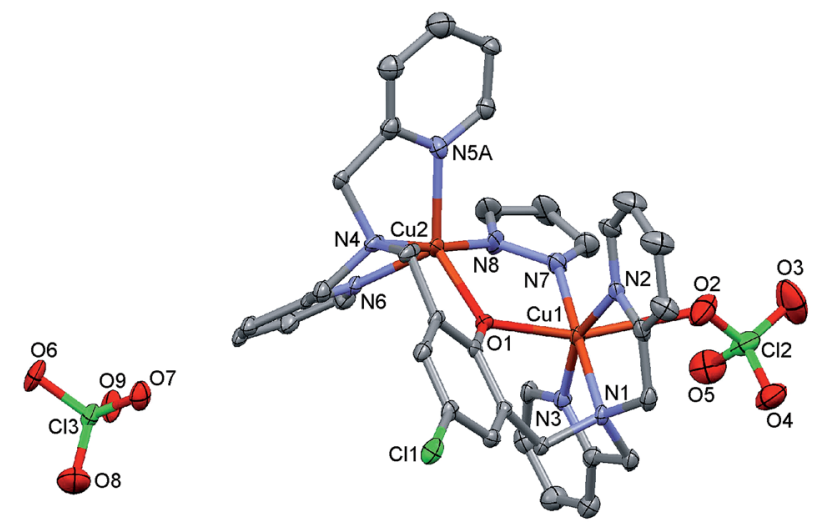

Fig. 2 Perspective view and atom numbering scheme of the complex $\left[\mathrm{Cu}_{2}\left(\mathrm{~L}{ }^{\mathrm{Cl} O}\right)(\mu-\mathrm{pz})\left(\mathrm{ClO}_{4}\right)\right] \mathrm{ClO}_{4}$ (2). $\mathrm{H}$-atoms are omitted for clarity.

single deprotonated pyrazole, the bridging $\mathrm{O}(1)$ atom of central 4-chlorophenolate moiety and $\mathrm{O}(2)$ oxygen atom of a terminal perchlorate group. The four short $\mathrm{Cu}(1)-\mathrm{N}$ bond lengths are in the range from $1.957(5)$ to $2.020(6) \AA$. The axial $\mathrm{Cu}(1)-\mathrm{O}(1)$, $\mathrm{Cu}(1)-\mathrm{O}(2)$ and $\mathrm{O}(1)-\mathrm{Cu}(1)-\mathrm{O}(2)$ bond parameters are 2.227(4) $\mathrm{A}$, $2.769(7) \AA$ and $157.87(17)^{\circ}$, respectively. $\mathrm{Cu}(2)$ is pentacoordinated by three $\mathrm{N}$ donor atoms of second disordered bispyridylamino group, $\mathrm{N}(8)$ of a bridging single pyrazolyl anion, and the bridging $\mathrm{O}(1)$ atom of central 4-chloro-phenolate moiety. The $\mathrm{CuN}_{3} \mathrm{O}_{2}$ chromophore adopts a distorted TBP geometry [ $\tau$-value: 0.73 (for N5A) or 0.78 (for N5B)]. ${ }^{45}$ The axial sites are occupied by $\mathrm{N}(4)$ and $\mathrm{N}(8)$ atoms $[\mathrm{Cu}(2)-\mathrm{N}(4)=2.020(6) \AA$, $\left.\mathrm{Cu}(2)-\mathrm{N}(8)=1.994(7) \AA, \mathrm{N}(4)-\mathrm{Cu}(2)-\mathrm{N}(8)=174.1(2)^{\circ}\right]$. The equatorial $\mathrm{Cu}(2)-\mathrm{N} / \mathrm{O}$ bond distances are in the range from $1.997(10)$ to $2.186(11) \AA$. The $\mathrm{Cu}(1) \cdots \mathrm{Cu}(2)$ intra-dimeric distance is 3.4635(10) $\AA$, and the shortest inter-dimer metal-metal separation is $8.0887(11) \AA$. The $\mathrm{Cu}(1)-\mathrm{O}(1)-\mathrm{Cu}(2)$ bond angles is 108.85(18) $)^{\circ}$. Packing plot of the compound is shown in Fig. S7. $\dagger$

$\left[\mathbf{C u}_{2}\left(\mu-\mathbf{L}^{\mathbf{C l}} \mathbf{O}\right)\left(\mu-\mathbf{O}_{2} \mathbf{P}\left(\mathbf{O C}_{6} \mathbf{H}_{5}\right)_{2}\right)\right]\left(\mathbf{C l O}_{4}\right)_{2} \quad$ (3). The molecular structure of 3 consists of dinuclear $\left[\mathrm{Cu}_{2}\left(\mathrm{~L}^{\mathrm{Cl}} \mathrm{O}\right)\left(\mathrm{O}_{2} \mathrm{P}\left(\mathrm{OC}_{6} \mathrm{H}_{5}\right)_{2}\right)\right]^{2+}$ complex cations and $\mathrm{ClO}_{4}{ }^{-}$counter ions. A perspective view of the complex cation together with partial atom numbering scheme is given in Fig. 3 and selected bond parameters are

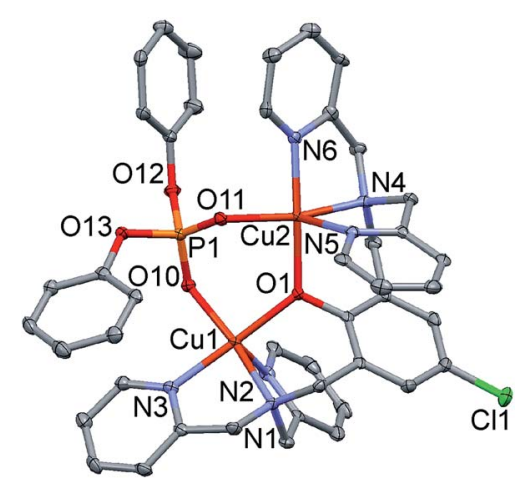

Fig. 3 Perspective view and atom numbering scheme of the dinuclear unit, $\left[\mathrm{Cu}_{2}\left(\mathrm{~L}^{\mathrm{Cl}}-\mathrm{O}\right)\left(\mu-\left(\mathrm{PO}_{2}\left(\mathrm{OC}_{6} \mathrm{H}_{5}\right)_{2}\right)\right)\right]^{2+}$ of complex 3 . H-atoms are omitted for clarity. summarized in Table S3. $\dagger$ Each $\mathrm{Cu}(\mathrm{II})$ center within the dinuclear complex cation is penta-coordinated by three $\mathrm{N}$-donor atoms of one bis-pyridylamino group, the bridging $\mathrm{O}(1)$ atom of central 4-chlorophenolate moiety and an oxygen atom of bridging $\left(\mathrm{PO}_{2}\right)\left(\mathrm{OC}_{6} \mathrm{H}_{5}\right)_{2}$ group. Both $\mathrm{CuN}_{3} \mathrm{O}_{2}$ chromophores adopt distorted SP geometry $[\tau$-values: 0.09 and 0.16 , for $\mathrm{Cu}(1)$ and $\mathrm{Cu}(2)$, respectively ${ }^{45}$ with $\mathrm{N}(2)$ and $\mathrm{N}(5)$ atoms in apical sites $[\mathrm{Cu}(1)-\mathrm{N}(2)=2.140(4), \mathrm{Cu}(2)-\mathrm{N}(5)=2.173(4) \AA]$. The basal $\mathrm{Cu}-\mathrm{N} / \mathrm{O}$ bond distances are in the range from 1.959(3) to 2.054(4) $\AA$. The $\mathrm{Cu}(1) \cdots \mathrm{Cu}(2)$ intra-dimeric distance is 3.5884(10) $\AA$, and the shortest inter-dimer metal-metal separation is 6.7623(12) A. The $\mathrm{Cu}(1)-\mathrm{O}(1)-\mathrm{Cu}(2), \mathrm{Cu}(1)-\mathrm{O}(10)-\mathrm{P}(1)$, and $\mathrm{Cu}(2)-\mathrm{O}(11)-\mathrm{P}(1)$ bond angles are 126.90(17), 124.1(2) and 120.1(2) ${ }^{\circ}$, respectively. Packing plot of compound 3 is shown in Fig. S8. $\dagger$

$\left[\mathrm{Cu}_{2}\left(\mu-\mathrm{L}^{\mathrm{Cl}} \mathrm{O}\right)(\mathrm{dca})_{2}\right] \mathrm{PF}_{6} \cdot 2 \mathrm{MeCN}(4 \cdot 2 \mathrm{MeCN})$ and $\left[\mathrm{Cu}_{2}\left(\mu-\mathrm{L}^{\mathrm{Me}} \mathrm{O}\right)-\right.$ (dca $\left.)_{2}\right] \mathbf{P F}_{6} \cdot 2 \mathrm{MeCN}(5 \cdot 2 \mathrm{MeCN})$. The molecular structures of these molecules consist of dinuclear complex cations $\left[\mathrm{Cu}_{2}\left(\mathrm{~L}^{\mathrm{Cl}} \mathrm{O}\right)\right.$ $\left.(\mathrm{dca})_{2}\right]^{+}$or $\left[\mathrm{Cu}_{2}\left(\mathrm{~L}^{\mathrm{Me}} \mathrm{O}\right)(\mathrm{dca})_{2}\right]^{+}, \mathrm{PF}_{6}{ }^{-}$counter ions and $\mathrm{MeCN}$ lattice solvent molecules. Perspective views of the crystal structures together with partial atom numbering schemes are depicted in Fig. 4, and selected bond parameters are presented in Tables $\mathrm{S} 4$ and $\mathrm{S} 5, \uparrow$ respectively. Each $\mathrm{Cu}(\mathrm{II})$ center within a dinuclear complex cation is penta-coordinated by three $\mathrm{N}$ donor atoms of one bis-pyridylamino group, a terminal dicyanamide anion in basal sites, and the bridging $\mathrm{O}(1)$ atom of central 4-substituted-phenolate moiety, which occupies the axial position of the distorted square pyramids [ $\tau$-values: 0.05 and 0.07 for 4 and 0.05 and 0.04 for 5$]{ }^{45}$ The corresponding axial $\mathrm{Cu}-\mathrm{O}(1)$ bond distances are 2.190(5), 2.190(5), 2.170(2) and 2.172(2) Å, respectively. The basal $\mathrm{Cu}-\mathrm{N}$ bond distances are in the range from 1.961(5) to 2.058(6) ̊. The $\mathrm{Cu}(1)-\mathrm{O}(1)-\mathrm{Cu}(2)$ bridging bond angles are $136.82(17)$ and $137.65(8)^{\circ}$, respectively. The intradimeric metal $\cdots$ metal distances are $4.0727(12)$ and $4.0492(5) \AA$, and the shortest inter-dimer metal-metal separations are 8.3646(12) and 8.3684(6) ^, for 4 and 5, respectively (Fig. S9 and $\mathrm{S} 10 \dagger)$. The terminal dicyanamido ligands have the following bond parameters: $\mathrm{C}-\mathrm{N}($ nitrile): 1.142(4)-1.174(8) $\mathrm{A}, \mathrm{C}-\mathrm{N}($ amide): 1.288(9)-1.342(11) $\quad \mathrm{A}, \quad \mathrm{N}-\mathrm{C}-\mathrm{N}: \quad 173.5(3)-175.0(9)^{\circ}, \quad \mathrm{C}-\mathrm{N}-\mathrm{C}$ : $117.8(7)-119.9(3)^{\circ}, \mathrm{Cu}-\mathrm{N}-\mathrm{C}: 160.8(3)-164.7(3)^{\circ}$.

\section{Magnetic properties of complexes}

The analysis of the magnetic data was based on the spin Hamiltonian for dinuclear system of the form

$$
\hat{H}=-J\left(\vec{S}_{1} \vec{S}_{2}\right)+\sum_{i=1}^{2} \mu_{\mathrm{B}} B g_{i} \hat{S}_{i, z}
$$

where the isotropic exchange $(J)$ and Zeeman term $(g)$ are included. Then, the molar magnetization can be easily calculated using the following analytical formula ${ }^{46}$

$$
M_{\mathrm{mol}}=\mu_{\mathrm{B}} g N_{\mathrm{A}} \frac{\mathrm{e}^{(J+x) / k T}-\mathrm{e}^{(J-x) / k T}}{1+\mathrm{e}^{(J+x) / k T}+\mathrm{e}^{J / k T}+\mathrm{e}^{(J-x) / k T}}
$$

where $x=\mu_{\mathrm{B}} g B$.

Moreover, the small amount of monomeric paramagnetic impurity (PI) which accounts for increase of molar 
a)

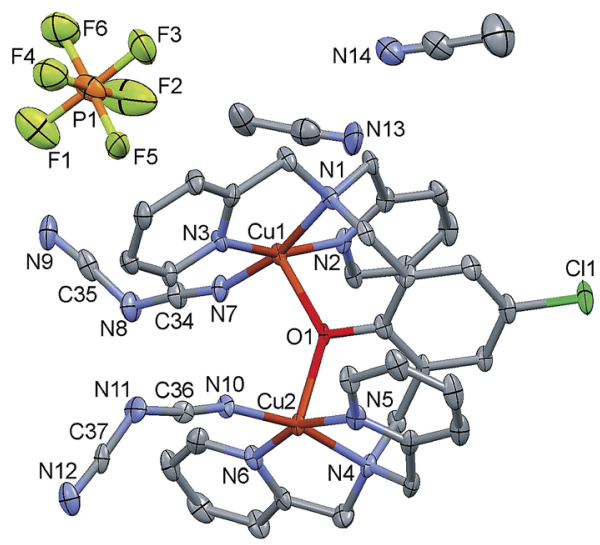

b)

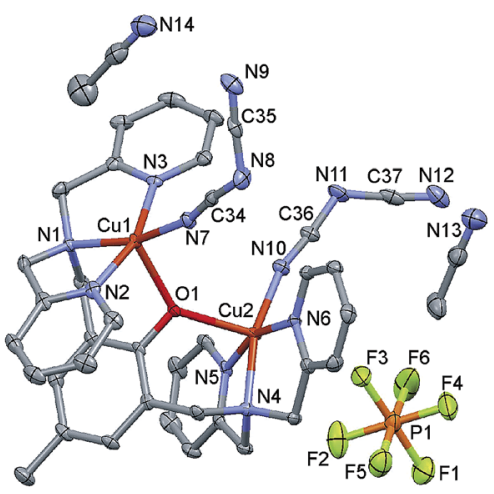

Fig. 4 Perspective views and atom numbering schemes of the dicyanamido complexes: (a) $\left[\mathrm{Cu}_{2}\left(\mathrm{~L}^{\mathrm{Cl} O}\right)(\mathrm{dca})_{2}\right] \mathrm{PF} \cdot 2 \mathrm{CH}_{3} \mathrm{CN}\left(4 \cdot 2 \mathrm{CH}_{3} \mathrm{CN}\right)$ and $(\mathrm{b})$ $\left[\mathrm{Cu}_{2}(\mathrm{~L} \mathrm{Me} \mathrm{O})(\mathrm{dca})_{2}\right] \mathrm{PF}_{6} \cdot 2 \mathrm{CH}_{3} \mathrm{CN}\left(5 \cdot 2 \mathrm{CH}_{3} \mathrm{CN}\right)$. $\mathrm{H}$-atoms are omitted for clarity.

magnetization (mean susceptibility) at low temperatures was taken into consideration by eqn (3)

$$
M_{\text {sample }}=\left(1-\chi_{\mathrm{PI}}\right) M_{\mathrm{mol}}+2 \chi_{\mathrm{PI}} M_{\mathrm{PI}}
$$

where $M_{\mathrm{PI}}$ was calculated using the Brillouin function. Both temperature and field dependent magnetic data of the studied compounds were included into fitting procedures.

The experimental magnetic data of $\mathbf{1}$ are depicted in Fig. 5. The theoretical effective magnetic moment $\mu_{\text {eff }}$ for two uncoupled $S_{1}=S_{2}=1 / 2$ and $g=2.0$ is $2.45 \mu_{\mathrm{B}}$ or for more typical value of $g$-factor for copper(II) compounds equaled to 2.2 is $\mu_{\text {eff }} / \mu_{\mathrm{B}}=$ 2.69. The room temperature value of $\mu_{\text {eff }}$ is $2.06 \mu_{\mathrm{B}}$ and is decreasing on lowering the temperature. The presence of two maxima of $M_{\mathrm{mol}} v s$. $T$ curve located at $T_{\max , 1}=52.3 \mathrm{~K}$ and $T_{\max , 1}$ $=213.3 \mathrm{~K}$ suggests that most likely the sample was contaminated by unidentified impurity, which was not detected by standard physico-chemical methods. Probably, it should be mentioned that several independently prepared batches of the complex were tested and same result was obtained. However,
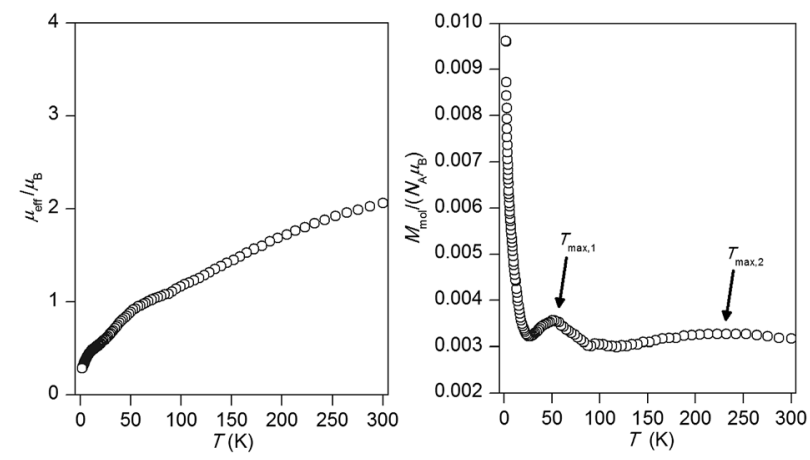

Fig. 5 The magnetic data for complex 1: the temperature dependence of the effective magnetic moment (left) and molar magnetization measured at $B=1 \mathrm{~T}$ (right). The arrows point to maxima found at $T_{\max , 1}=52.3 \mathrm{~K}$ and $T_{\max , 2}=213 \mathrm{~K}$. there is a simple formula derived for dinuclear species which can be used to estimate $J$-value as ${ }^{46}$

$$
|J| / k T_{\max }=1.599
$$

Then, the first maximum corresponds to $J_{1}=-58.2 \mathrm{~cm}^{-1}$, while the second one to $J_{2}=-237 \mathrm{~cm}^{-1}$. The $J_{1}$ spans the interval between DFT calculated values (see next section) $J^{\text {Ruiz }}=-43.1 \mathrm{~cm}^{-1}$ and $J^{\text {Yam }}=-85.5 \mathrm{~cm}^{-1}$, so it can be suggested that $J_{1}$ matches the predicted magnetism of compound $\mathbf{1}$, while the $J_{2}$ may be assigned to the unknown impurity.

Contrary to the case described above, the experimental magnetic data for 2 (Fig. 6) matches well with the expectations where the effective magnetic moment is close to $2.7 \mu_{\mathrm{B}}$ at $300 \mathrm{~K}$ and continuously decreases to $0.24 \mu_{\mathrm{B}}$ at $1.9 \mathrm{~K}$. The maximum of $M_{\text {mol }} v s$. $T$ curve is located at $T_{\max }=55.1 \mathrm{~K}$, which corresponds to $J=-61.2 \mathrm{~cm}^{-1}$. Fitting procedure, which was done according to eqn (1)-(3), resulted in $J=-61.5 \mathrm{~cm}^{-1}, g=2.14, \chi_{\mathrm{TIP}}=3.9 \times$
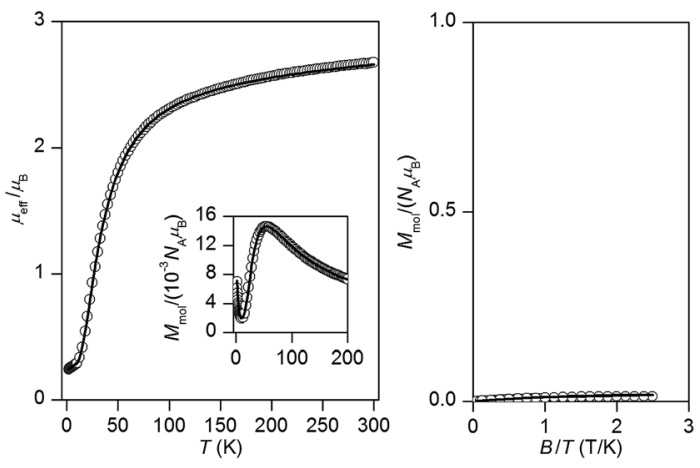

Fig. 6 The magnetic data for 2. Left: The temperature dependence of the effective magnetic moment and molar magnetization measured at $B=1 \mathrm{~T}$. Right: The isothermal magnetizations measured at $T=2$ and $5 \mathrm{~K}$. Open circles - experimental data, solid lines - calculated data using the eqn (1) with $\mathrm{J}=-61.5 \mathrm{~cm}^{-1}, g=2.14, \chi_{\mathrm{TIP}}=3.9 \times 10^{-9}$ $\mathrm{m}^{3} \mathrm{~mol}^{-1}, \chi_{\mathrm{PI}}=0.85 \%$. 

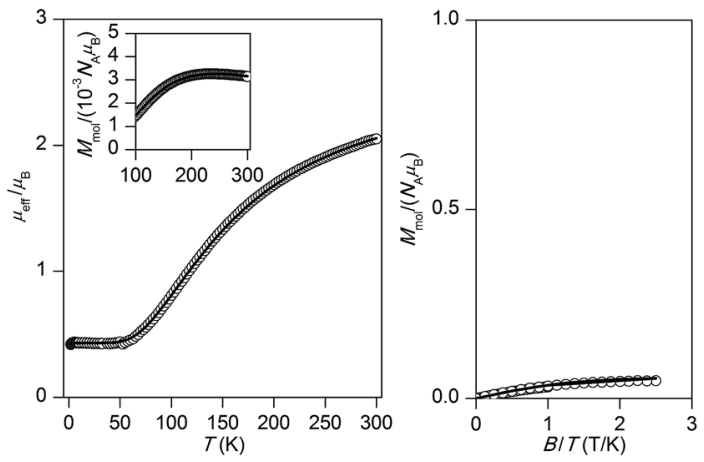

Fig. 7 The magnetic data for 3. Left: The temperature dependence of the effective magnetic moment and molar magnetization measured at $B=1 \mathrm{~T}$. Right: The isothermal magnetizations measured at $T=2$ and $5 \mathrm{~K}$. Open circles - experimental data, solid lines - calculated data using the eqn (1), with $\mathrm{J}=-279 \mathrm{~cm}^{-1}, g=2.17, \chi_{\mathrm{TIP}}=0.0 \times 10^{-9}$ $\mathrm{m}^{3} \mathrm{~mol}^{-1}, \chi_{\mathrm{PI}}=2.60 \%$.

$10^{-9} \mathrm{~m}^{3} \mathrm{~mol}^{-1}, \chi_{\mathrm{PI}}=0.85 \%$, where $\chi_{\mathrm{TIP}}$ represents the correction to the temperature-independent magnetism (TIP). The strong antiferromagnetic exchange in $\mathbf{3}$, as compared to 2 , is simply evident by its experimental magnetic data (Fig. 7), where $T_{\max }$ located at $243 \mathrm{~K}$ was served as an estimate for $J=$ $-270 \mathrm{~cm}^{-1}$. This value is close to that found by the fitting procedure: $J=-279 \mathrm{~cm}^{-1}, g=2.17, \chi_{\mathrm{TIP}}=0.0 \times 10^{-9}$ $\mathrm{m}^{3} \mathrm{~mol}^{-1}, \chi_{\mathrm{PI}}=2.60 \%$.

For the remaining two dicyanamido compounds, $\left[\mathrm{Cu}_{2}\left(\mu-\mathrm{L}^{\mathrm{R}}-\mathrm{O}\right)\right.$ (dca) $\left.)_{2}\right] \mathrm{PF}_{6} \cdot 2 \mathrm{CH}_{3} \mathrm{CN}$ (4: $\mathrm{R}=\mathrm{Cl} ; 5: \mathrm{R}=\mathrm{CH}_{3}$ ), DFT calculations predicted almost negligible antiferromagnetic exchange (see next section). Indeed, the effective magnetic moment is almost constant over the whole temperature range (the gradual increase of $\mu_{\mathrm{eff}} / \mu_{\mathrm{B}}$ on heating in the case of 5 can be attributed to small amount of para/ferromagnetic impurity and due to temperatureindependent magnetism). There is no maximum of $M_{\text {mol }} v s . T$ curve, which suggests that the value of $|J|$ should be less than $2 \mathrm{~cm}^{-1}$. This agrees well with the fitted values: $J=-0.26 \mathrm{~cm}^{-1}$, $g=2.15, \chi_{\text {TIP }}=1.0 \times 10^{-9} \mathrm{~m}^{3} \mathrm{~mol}^{-1}$ for 4 and $J=-0.11 \mathrm{~cm}^{-1}$, $g=2.08, \chi_{\text {TIP }}=1.9 \times 10^{-9} \mathrm{~m}^{3} \mathrm{~mol}^{-1}$ for 5 (Fig. 8 and 9).
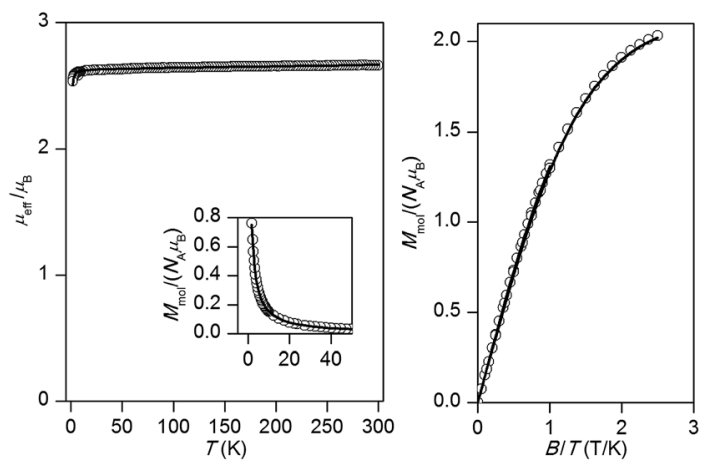

Fig. 8 The magnetic data for 4. Left: The temperature dependence of the effective magnetic moment and molar magnetization measured at $B=1 \mathrm{~T}$. Right: The isothermal magnetizations measured at $T=2$ and $5 \mathrm{~K}$. Open circles - experimental data, solid lines - calculated data using the eqn (1), with $J=-0.26 \mathrm{~cm}^{-1}, g=2.15, \chi_{\mathrm{TIP}}=1.0 \times 10^{-9} \mathrm{~m}^{3} \mathrm{~mol}^{-1}$.
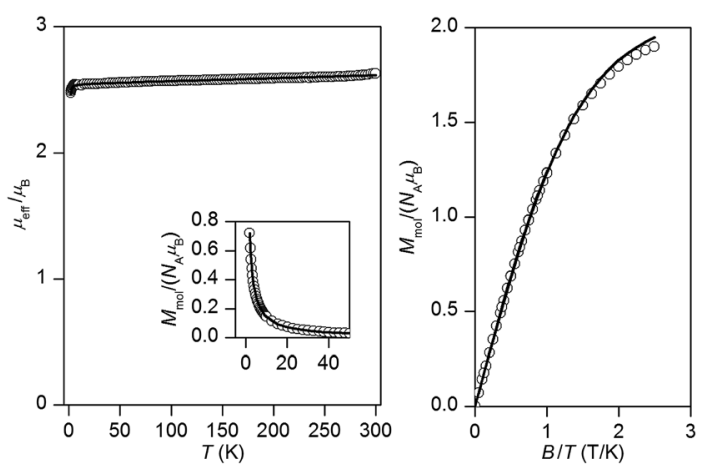

Fig. 9 The magnetic data for 5. Left: The temperature dependence of the effective magnetic moment and molar magnetization measured at $B=1 \mathrm{~T}$. Right: The isothermal magnetizations measured at $T=2$ and $5 \mathrm{~K}$. Open circles - experimental data, solid lines - calculated data using the eqn (1), with $J=-0.11 \mathrm{~cm}^{-1}, g=2.08, \chi_{\mathrm{TIP}}=1.9 \times 10^{-9} \mathrm{~m}^{3} \mathrm{~mol}^{-1}$.

\section{DFT calculations}

Our previous study on dinuclear singly bridged-phenoxido metal(II) complexes showed that in the case of copper(II) complex of the type $\left[\mathrm{Cu}_{2}\left(\mu-\mathrm{L}^{\mathrm{Cl}}-\mathrm{O}\right) \mathrm{Cl}_{2}\right] \mathrm{PF}_{6} \cdot 1 / 2 \mathrm{MeOH}$, there is a very weak antiferromagnetic exchange due to ineffective overlap of non-orthogonal magnetic orbitals. ${ }^{1}$ In the present study there are additional bridging ligands in compounds 1-3, therefore the DFT calculations were performed to reveal the effect of these extra bridging on the magnetic properties. Thus, we calculated the isotropic exchange parameters $J$ using the ORCA 3.0 software for compounds 1-3 and extended the calculations also for compounds $\mathbf{4}$ and $\mathbf{5}$ for comparison purposes. Following our previous study ${ }^{1}$ we used the B3LYP functional and def2TZVP(-f) basis set to calculate the energy difference $\Delta$, between high spin (HS) and broken-symmetry (BS) spin states:

$$
\Delta=E_{\mathrm{BS}}-E_{\mathrm{HS}}
$$

This energy difference is then used to calculate $J$-value for the dinuclear spin Hamiltonian defined as

$$
\hat{H}=-J\left(\vec{S}_{1} \vec{S}_{2}\right)
$$

by both Ruiz's approach

$$
J^{\text {Ruiz }}=2 \Delta /\left[\left(S_{1}+S_{2}\right)\left(S_{1}+S_{2}+1\right)\right]
$$

and by Yamaguchi's approach

$$
J^{\mathrm{Yam}}=2 \Delta /\left[\left\langle S^{2}\right\rangle_{\mathrm{HS}}-\left\langle S^{2}\right\rangle_{\mathrm{BS}}\right]
$$

The results of DFT calculations are summarized in Table 1 and illustrated in Fig. 10. All the $J$-values were found negative and suggesting the presence of antiferromagnetic coupling ranging from very weak (5) to very strong (3). In case of squarepyramidal geometry (SP) the unpaired electron resides in $\mathrm{d}_{x^{2}-y^{2}}$ orbitals, while the corresponding trigonal-bipyramid (TBP) geometry resulted in magnetic orbital based on $\mathrm{d}_{z^{2}}(\mathrm{Cu} 2$ in compound 2). The smallest overlap $S_{\alpha \beta}$ between the non- 
Table 1 The DFT-calculated net Mulliken spin densities $(\rho)$, expected values $\left\langle S^{2}\right\rangle$, overlap $S_{\alpha \beta}$ between the corresponding orbitals and isotropic exchange parameters (J) from high-spin (HS) and broken symmetry spin (BS) states of the dinuclear molecular fragments based on X-ray structures of 1-9 completed with selected structural parameters

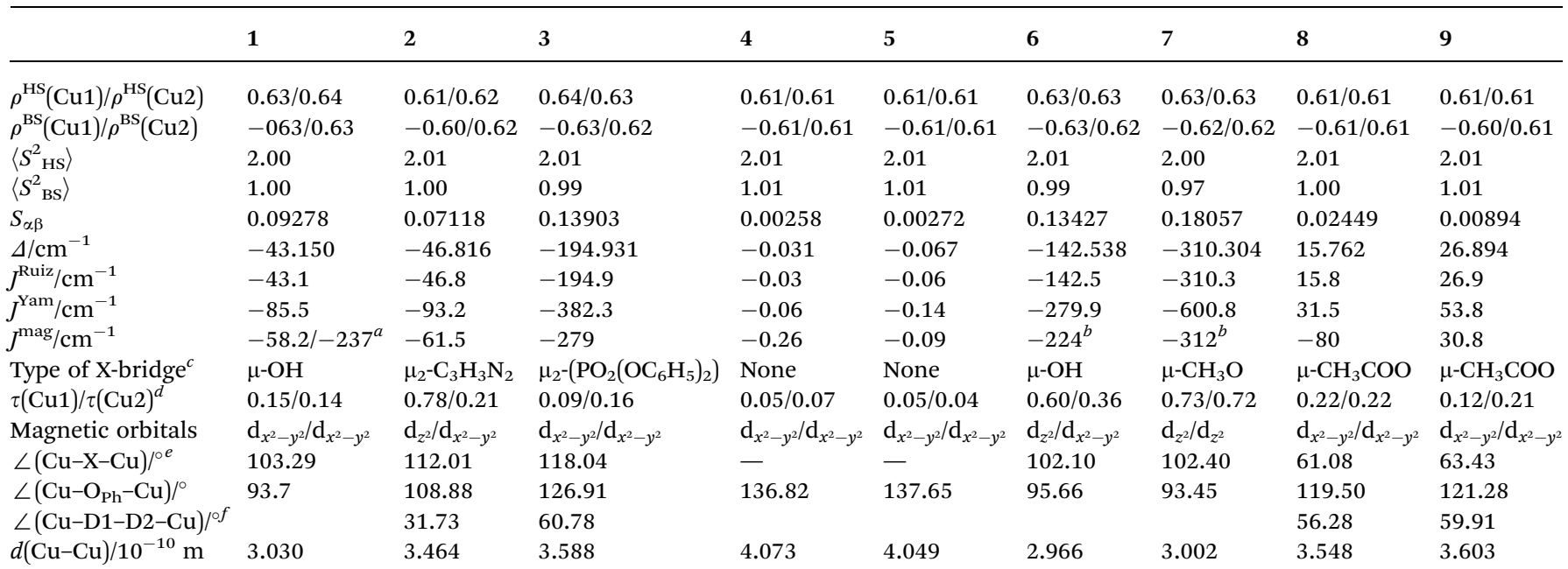

${ }^{a} \mathrm{~J}$-values are estimated from maxima of molar susceptibility. ${ }^{b} \mathrm{~J}$-values were reported in ref. 28 and 34 and scaled according to eqn (1). ${ }^{c}$ See Chart 1. ${ }^{d}$ The $\tau$-parameters were calculated by assuming pentacoordination of copper atoms, hence neglecting semi-coordination of the perchlorate anion in 1 and $2 .{ }^{e}$ In the case of 2, 3 and $\mathbf{8 , 9}$ the angle was calculated between two bonds $\mathrm{Cu}-\mathrm{D} 1$ and $\mathrm{Cu}-\mathrm{D} 2$, where D1 and D2 are donor atoms of bridging ligand $\mathrm{X} .{ }^{f}$ In the case of $\mathbf{2 , 3}$ and $\mathbf{8}, \mathbf{9}$, the dihedral angle was calculated between $\mathrm{Cu}-\mathrm{D} 1-\mathrm{D} 2-\mathrm{Cu}$ atoms, where D1 and D2 are donor atoms of the bridging ligand $\mathrm{X}$.

orthogonal orbitals was found for 5 and the largest for 3, which is in agreement with strength of antiferromagnetic exchange.

Careful inspection of literature showed that there are only four other examples similar to ours where the magnetic properties were studied for copper(II) dimers containing both $\mathrm{L}^{\mathrm{R}}-\mathrm{OH}$ and $\mathrm{X}$ ligands (Chart 1), namely $\left[\mathrm{Cu}_{2}\left(\mu-\mathrm{L}^{\mathrm{Me}} \mathrm{O}\right)(\mu-\mathrm{OH})\right]\left(\mathrm{ClO}_{4}\right)_{2} \cdot \mathrm{THF}(6),{ }^{28}$
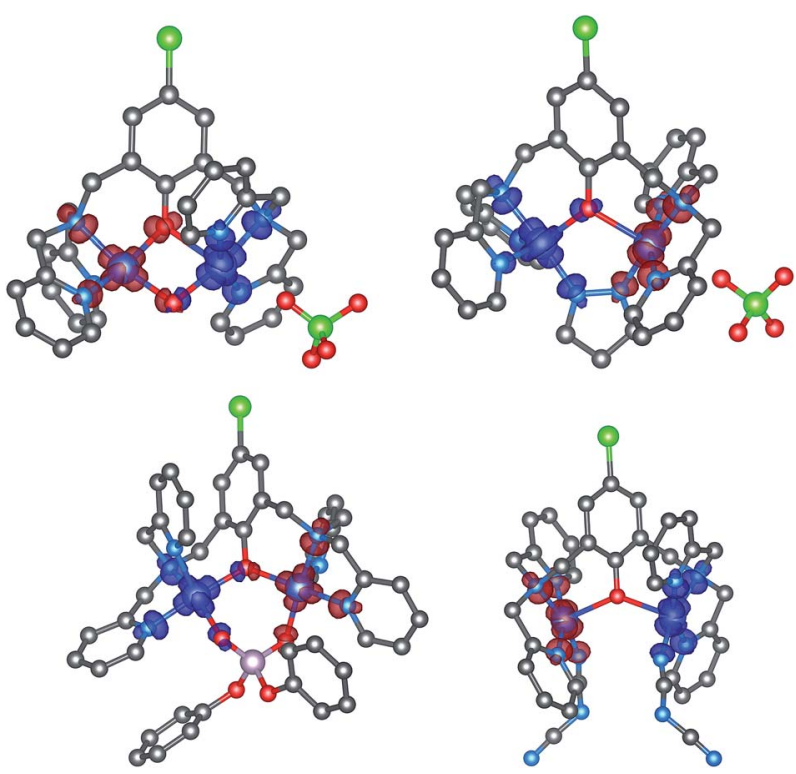

Fig. 10 The calculated the isodensity surfaces of the broken symmetry spin states using B3LYP/def2-TZVP(-f) for molecular fragments of 1-4. Positive and negative spin densities are represented by dark blue, and dark red surfaces, respectively. Hydrogen atoms were omitted for clarity.
$\left[\mathrm{Cu}_{2}\left(\mu-\mathrm{L}^{t \mathrm{Bu}} \mathrm{O}\right)\left(\mu-\mathrm{OCH}_{3}\right)\right]\left(\mathrm{ClO}_{4}\right)_{2} \cdot \mathrm{H}_{2} \mathrm{O} \quad(7),{ }^{34} \quad\left[\mathrm{Cu}_{2}\left(\mu-\mathrm{L}^{\mathrm{Me}} \mathrm{O}\right)\left(\mu-\mathrm{CH}_{3}-\right.\right.$ $\mathrm{COO})]\left(\mathrm{PF}_{6}\right)_{2}(8),{ }^{4}$ and $\left[\mathrm{Cu}_{2}\left(\mu-\mathrm{L}^{t \mathrm{Bu}} \mathrm{O}\right)\left(\mu-\mathrm{CH}_{3} \mathrm{COO}\right)\right]\left(\mathrm{PF}_{6}\right)_{2}(9)^{47}$ with $J^{\mathrm{mag}}=-224,-312,-80,+30.8 \mathrm{~cm}^{-1}$, respectively. The reported $J^{\text {mag }}$ values were scaled according to the spin Hamiltonian definition in eqn (1). Interestingly, compounds 1, 6 and 7 have the same hydroxo/alkoxo-bridging groups $\left(\mathrm{X}=\mathrm{OH}^{-} / \mathrm{CH}_{3} \mathrm{O}^{-}\right)$and despite the fact that structural parameters defining the bridges, like $\mathrm{Cu}-\mathrm{O}_{\mathrm{Ph}}-\mathrm{Cu}\left(93.45-95.66^{\circ}\right)$ and $\mathrm{Cu}-\mathrm{O}_{\mathrm{X}}-\mathrm{Cu}\left(102.1-103.29^{\circ}\right)$ angles or $\mathrm{Cu} \cdots \mathrm{Cu}$ distances (2.966-3.030 $\mathrm{\AA}$ ) are almost the same (Table 1 ), the $J^{\mathrm{mag}}$ values vary significantly. More interesting is also the comparison of the $J^{\mathrm{mag}}$ values for acetato-bridged complexes $\mathbf{8}$ and $\mathbf{9}$, which are structurally almost identical (Table 1), their reported magnetic exchanges are either antiferromagnetic or ferromagnetic. Therefore, we utilized the above described DFT procedure to calculate the magnetic exchange parameters also for compounds 6-9 in order to elucidate the observed large variations of the isotropic exchange parameters within this family of coordination compounds. The main results are listed in Table 1 and illustrated in Fig. 10 and 11. Within the structurally similar first group of compounds 1, $\mathbf{6}$ and 7, it is obvious that the calculated strength of the antiferromagnetic exchange $\left(J^{\text {Ruiz }} / J^{\text {Yam }}\right)$ increases with increasing the overlap of magnetic orbitals $\left(S_{\alpha \beta}\right): \mathrm{d}_{x^{2}-y^{2}} / \mathrm{d}_{x^{2}-y^{2}}$ $<\mathrm{d}_{z^{2}} / \mathrm{d}_{x^{2}-y^{2}}<\mathrm{d}_{z^{2}} / \mathrm{d}_{z^{2}}$. Thus, we may conclude that the main source of variation of magnetic properties in 1, 6 and 7 is due to the different geometry around the central copper ions (SP vs. TB). The large difference in $J^{\mathrm{mag}}$ for compounds $2\left(J^{\mathrm{mag}}=-61.5 \mathrm{~cm}^{-1}\right)$ and $3\left(J^{\mathrm{mag}}=-279 \mathrm{~cm}^{-1}\right)$ with the bridging ligands $\mathrm{X}(\mathrm{X}=$ the pyrazolyl anion for 2 and diphenylphosphate anion for 3) can be explained by the fact that in the case of the diphenylphosphato ligand, there is efficient overlap of orbitals $\left(\mathrm{d}_{x^{2}-y^{2}} / \mathrm{d}_{x^{2}-y^{2}}\right)$ through both bridging ligands, whereas in compound 3 , the $\mu$-phenoxido 

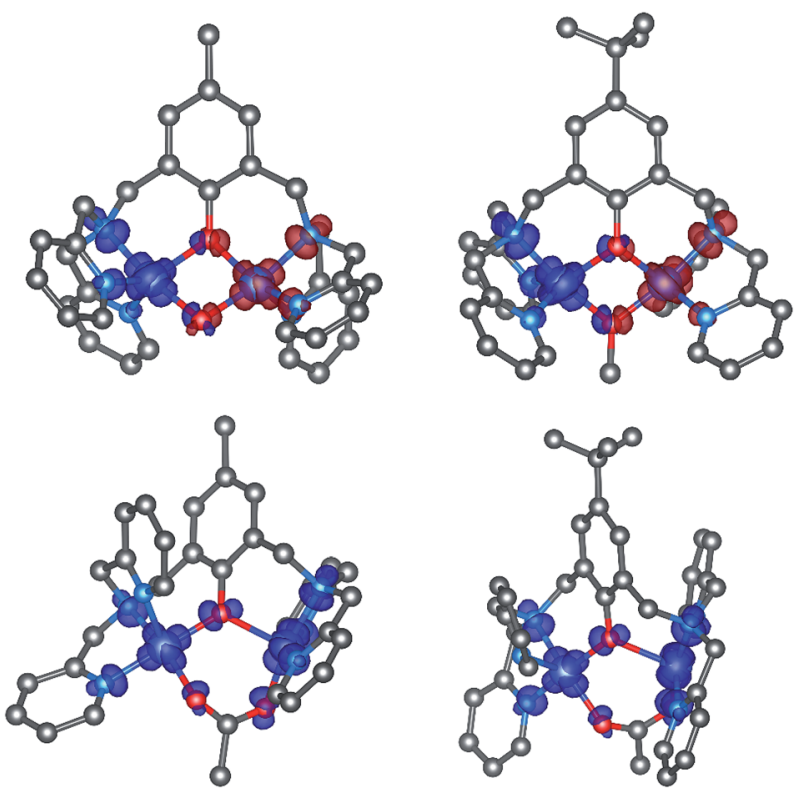

Fig. 11 The calculated isodensity surfaces of the broken symmetry spin states for molecular fragments of 6 and 7 and high spin states for molecular fragments of 8 and 9 using B3LYP/def2-TZVP(-f). Positive and negative spin densities are represented by dark blue, and dark red surfaces, respectively. Hydrogen atoms were omitted for clarity.

ligand is ineffective for overlap of the $\mathrm{d}_{z^{2}} / \mathrm{d}_{x^{2}-y^{2}}$ orbitals and thus only the $\mu$-pyrazolato ligand is the one that mediates magnetic exchange (Fig. 10). Next, in singly bridged-phenoxido compounds 4 and 5, the $\mathrm{d}_{x^{2}-y^{2}} / \mathrm{d}_{x^{2}-y^{2}}$ orbitals are lying in $\mathrm{CuN}_{4}$ planes perpendicular to the $\mathrm{Cu}-\mathrm{O}_{\mathrm{Ph}}$ bond, which leads to their negligible overlap, and hence to a very weak antiferromagnetic exchange similar to the previously observed in $\left[\mathrm{Cu}_{2}\left(\mu-\mathrm{L}^{\mathrm{Cl}} \mathrm{O}\right) \mathrm{Cl}_{2}\right] \mathrm{PF}_{6} \cdot 1 /$ $2 \mathrm{MeOH} .{ }^{1}$ Finally, we would like to comment on the results of compounds 8 and $\mathbf{9}$. In these compounds $\mathbf{8}$, the magnetic orbitals have $\mathrm{d}_{x^{2}-y^{2}} / \mathrm{d}_{x^{2}-y^{2}}$ character and their mutual orientation exclude their efficient overlap through the $\mu$-phenoxido ligand and also through acetato ligand (Fig. 11), which results in calculated ferromagnetic exchange, $J^{\mathrm{Ruiz}} / J^{\mathrm{Yam}}=15.8 / 31.5 \mathrm{~cm}^{-1}$ for 8 and $J^{\text {Ruiz }} / J^{\text {Yam }}=26.9 / 53.8 \mathrm{~cm}^{-1}$ for 9 (Table 1 ). The variation in the calculated $J$-values in $\mathbf{8}$ and $\mathbf{9}$ can be most probably attributed to the small differences in orientation of acetato-ligand with respect to both $\mathrm{CuN}_{2} \mathrm{O}_{2}$ planes containing magnetic orbitals with $\mathrm{d}_{x^{2}-y^{2}} / \mathrm{d}_{x^{2}-y^{2}}$ character. ${ }^{48}$ This can be demonstrated by evaluating the angle between plane of the acetato-ligand and $\mathrm{CuN}_{2} \mathrm{O}_{2}$ planes, which resulted in values $52.25^{\circ}$ and $67.98^{\circ}$ for 8 and $60.92^{\circ}$ and $66.61^{\circ}$ for $\mathbf{9}$.

Furthermore, the reliability and suitability of the DFT method used here for calculation of $J$-parameters can be judged by inspecting Fig. 12, where all the calculated $J$-values are compared to those determined by the experimental magnetic data. We can conclude that except for compound 8, the experimental values $J^{\text {mag }}$ are found within the intervals defined by calculated $J^{\mathrm{Ruiz}} / J^{\mathrm{Yam}}$ values, which means that this procedure can reliably determine the nature of the isotropic exchange (antiferromagnetic/ferromagnetic) and also quite accurate in predicting quantitative values of $J$-parameters for this family of copper(II) dimeric complexes.

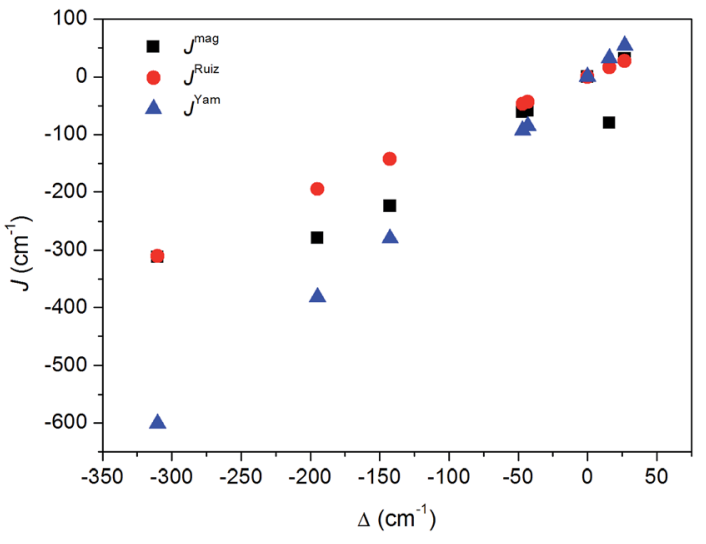

Fig. 12 Comparison of the experimentally $\left(J^{\text {mag }}\right)$ and theoretically ( $J^{\text {Ruiz }}$ and $J^{\mathrm{Yam}}$ ) determined isotropic exchange parameters $v s$. calculated energy difference $\Delta,\left(\Delta=E_{\mathrm{BS}}-E_{\mathrm{HS}}\right)$.

\section{Experimental}

\section{Materials and physical measurements}

The compound bis(2-pyridylmethyl)amine (DPA) was purchased from TCI-America. All other chemicals were commercially available and used without further purification. The ligands 2,6-bis[bis(2-pyridylmethyl)aminomethyl]-4-chlorophenol $\left(\mathrm{L}^{\mathrm{Cl}}-\mathrm{OH}\right)$ and 2,6-bis[bis(2-pyridylmethyl)aminomethyl]-4-methylphenol $\left(\mathrm{L}^{\mathrm{Me}}-\mathrm{OH}\right)(\mathrm{Chart} 1)$ were prepared and characterized according to the published procedure. ${ }^{1,2}$ Infrared spectra of all complexes and ligands were recorded on a JASCO FTIR-480 plus spectrometer as $\mathrm{KBr}$ pellets, except complex 4 was measured using Nexus 670 spectrometer (ATR) (Thermo Nicolet, USA). Electronic spectra were recorded using an Agilent 8453 HP diode array UV-Vis spectrophotometer. ${ }^{1} \mathrm{H}$ and ${ }^{13} \mathrm{C}$ NMR spectra were obtained at room temperature on a Varian 400 NMR spectrometer operating at $400 \mathrm{MHz}\left({ }^{1} \mathrm{H}\right)$ and $100 \mathrm{MHz}\left({ }^{13} \mathrm{C}\right) .{ }^{1} \mathrm{H}$ and ${ }^{13} \mathrm{C}$ NMR chemical shifts $(\delta)$ are reported in ppm and were referenced internally to residual solvent resonances (DMSO- $\mathrm{d}_{6}$ : $\left.\delta_{\mathrm{H}}=2.49, \delta_{\mathrm{C}}=39.4 \mathrm{ppm}\right)$. ESI-MS spectra were measured on an LC-MS Varian Saturn 2200 spectrometer. The conductivity measurements were performed using a Mettler Toledo Seven Easy conductivity meter and the cell constant was determined by the aid of $1413 \mu \mathrm{S} \mathrm{cm}^{-1}$ conductivity standard. The molar conductivity of the complexes were determined from $\Lambda_{\mathrm{M}}=$ $\left(1.0 \times 10^{3} \kappa\right) / M$, where $\kappa=$ cell constant and $M$ is the molar concentration of the complex. Magnetic measurements were performed with an MPMS XL7 SQUID magnetometer (Quantum Design, Inc.) $(T=1.9-300 \mathrm{~K}$ at $B=1 \mathrm{~T} ; B=0-5 \mathrm{~T}$ at $T=2$ and $5 \mathrm{~K}$ ). The magnetic data were corrected for diamagnetic susceptibilities. Elemental analyses were carried out by the Atlantic Microlaboratory, Norcross, Georgia U.S.A.

\section{Theoretical DFT calculations}

The $a b$ initio theoretical calculations were done with the ORCA 3.0 computational package ${ }^{49}$ using the B3LYP functional ${ }^{50}$ and polarized triple- $\zeta$ quality basis set def2-TZVP(-f) for all the complexes (including all the atoms). ${ }^{51}$ The single-point energy 
calculations were done on molecular fragments based on the experimental X-ray geometries: $\left[\mathrm{Cu}_{2}\left(\mu-\mathrm{L}^{\mathrm{Cl}}-\mathrm{O}\right)(\mu-\mathrm{OH})\left(\mathrm{ClO}_{4}\right)\right]^{+}$of $\mathbf{1}$, $\left[\mathrm{Cu}_{2}\left(\mu-\mathrm{L}^{\mathrm{Cl}} \mathrm{O}\right)(\mu-\mathrm{pz})\left(\mathrm{ClO}_{4}\right)\right]^{+}$of $2,\left[\mathrm{Cu}_{2}\left(\mu-\mathrm{L}^{\mathrm{Cl}}-\mathrm{O}\right)\left(\mu-\left(\mathrm{O}_{2} \mathrm{P}\left(\mathrm{OC}_{6} \mathrm{H}_{5}\right)_{2}\right)\right)\right]^{2+}$ of $3,\left[\mathrm{Cu}_{2}\left(\mu-\mathrm{L}^{\mathrm{Cl}}-\mathrm{O}\right)(\mathrm{dca})_{2}\right]^{+}$of $4 \cdot 2 \mathrm{CH}_{3} \mathrm{CN},\left[\mathrm{Cu}_{2}\left(\mu-\mathrm{L}^{\mathrm{Me}}-\mathrm{O}\right)(\mathrm{dca})_{2}\right]^{+}$of $5 \cdot 2 \mathrm{CH}_{3} \mathrm{CN},\left[\mathrm{Cu}_{2}\left(\mu-\mathrm{L}^{\mathrm{Me}} \mathrm{O}\right)(\mu-\mathrm{OH})\right]^{2+}$ of $\mathbf{6},\left[\mathrm{Cu}_{2}\left(\mu-\mathrm{L}^{t \mathrm{Bu}} \mathrm{O}\right)\left(\mu-\mathrm{CH}_{3} \mathrm{O}\right)\right]^{2+}$ of $7,\left[\mathrm{Cu}_{2}\left(\mu-\mathrm{L}^{\mathrm{Me}} \mathrm{O}\right)\left(\mu-\mathrm{CH}_{3} \mathrm{COO}\right)\right]^{2+}$ of 8 and $\left[\mathrm{Cu}_{2}\left(\mu-\mathrm{L}^{\mathrm{tBu}} \mathrm{O}\right)-\right.$ $\left.\left(\mu-\mathrm{CH}_{3} \mathrm{COO}\right)\right]^{2+}$ of 9. All the calculations utilized the RI approximation with the decontracted auxiliary def2-TZV/J Coulomb fitting basis set and the chain-of-spheres (RIJCOSX) approximation to exact exchange. ${ }^{52}$ Also, increased integration grids (Grid5 and GridX5 in ORCA convention) and tight SCF convergence criteria were used. The isotropic exchange parameters $J$ were calculated by comparing the energies of high-spin (HS) and broken-symmetry (BS) spin states utilizing both Ruiz's approach $^{53}$ and Yamaguchi's approach. ${ }^{54}$ Plots of spin densities were done by means of the VESTA 3 software. ${ }^{55}$

\section{X-ray crystal structure analysis}

The X-ray single-crystal data of compounds 1-5 were collected on a Bruker-AXS APEX CCD diffractometer at 100(2) K. The crystallographic data, conditions retained for the intensity data collection and some features of the structure refinements are listed in Table 2. The intensities were collected with Mo-K $\alpha$ radiation $(\lambda=0.71073 \AA)$. Data processing, Lorentz-polarization and absorption corrections were performed using APEX, and the SADABS computer programs. ${ }^{56}$ The structures were solved by direct methods and refined by full-matrix least-squares methods on $F^{2}$, using the SHELXTL ${ }^{57}$ program package. All non-hydrogen atoms were refined anisotropically. The hydrogen atoms were located from difference Fourier maps, assigned with isotropic displacement factors and included in the final refinement cycles by use of HFIX (parent $\mathrm{C}$ atom) or DFIX (parent $\mathrm{O}$ atom) utility of the SHELXTL program. Molecular plots were performed with the Mercury program. ${ }^{58}$ In case of 2, split occupancy of 0.508(7) and 0.492(7) were applied to disordered atoms of one pyridyl moiety.

Caution: Salts of perchlorate and their metal complexes are potentially explosive and should be handled with great care and in small quantities.

\section{Syntheses of the complexes}

$\left[\mathrm{Cu}_{2}\left(\mu-\mathrm{L}^{\mathrm{Cl}}-\mathrm{O}\right)(\mu-\mathrm{OH})\right]\left(\mathrm{ClO}_{4}\right)_{2}(\mathbf{1})$. To a mixture of $\mathrm{Cu}(\mathrm{ClO})_{2} \cdot 6 \mathrm{H}_{2} \mathrm{O}$ $(0.152 \mathrm{~g}, \quad 0.40 \mathrm{mmol})$ and 2,6-bis[bis(2-pyridylmethyl) aminomethyl]-4-chlorophenol $(0.110 \mathrm{~g}, 0.20 \mathrm{mmol})$ dissolved in $\mathrm{MeOH}(20 \mathrm{~mL})$, an aqueous solution of $\mathrm{Na}_{2} \mathrm{CO}_{3}(21 \mathrm{mg}, 0.20 \mathrm{mmol}$ dissolved in $3 \mathrm{~mL} \mathrm{H}_{2} \mathrm{O}$ ) was added. The resulting green solution was heated on a steam-bath for $10 \mathrm{~min}$, filtered while hot through celite and then allowed to stand at room temperature. The precipitate which was obtained was collected by filtration, washed with propan-2-ol and $\mathrm{Et}_{2} \mathrm{O}$ and then dried at room temperature (overall yield: $105 \mathrm{mg}, 59 \%$ ). Recrystallization of the product from $\mathrm{H}_{2} \mathrm{O}$ afforded green crystals suitable for X-ray structure determination. Characterization for 1: calcd for $\mathrm{C}_{32} \mathrm{H}_{31} \mathrm{Cl}_{3} \mathrm{Cu}_{2} \mathrm{~N}_{6} \mathrm{O}_{10}$ (MM $\left.=892.07 \mathrm{~g} \mathrm{~mol}^{-1}\right): \mathrm{C}, 43.04 ; \mathrm{H}, 3.50 ; \mathrm{N}, 9.41 \%$. Found: $\mathrm{C}, 42.96 ; \mathrm{H}$, $3.46 ; \mathrm{N}, 9.27 \%$. Selected IR bands $\left(\mathrm{cm}^{-1}\right): 3429(\mathrm{~m}, \mathrm{~b}) \nu(\mathrm{O}-\mathrm{H}) ; 1608$ (s), $1573(\mathrm{w}), 1483(\mathrm{~m}), 1466(\mathrm{~s}), 1440(\mathrm{~m})$ (pyridyl groups); 1092 (vs., b) $\nu_{\text {as }}(\mathrm{Cl}-\mathrm{O})$. UV-VIS spectrum $\left\{\lambda_{\max }, \mathrm{nm}\left(\varepsilon, \mathrm{M}^{-1} \mathrm{~cm}^{-1} / \mathrm{Cu}\right.\right.$ atom)\} in $\mathrm{CH}_{3} \mathrm{CN}: 805(137, \mathrm{~b})$. ESI-MS in $\mathrm{CH}_{3} \mathrm{CN}: \mathrm{m} / z=835.056$, 767.069, 361.037 (major peaks) and for negative ion: $\mathrm{m} / \mathrm{z}=98.949$ (100\%). Molar conductivity, $\Lambda_{\mathrm{M}}\left(\mathrm{CH}_{3} \mathrm{CN}\right)=267 \Omega^{-1} \mathrm{~cm}^{2} \mathrm{~mol}^{-1}$.

$\left[\mathrm{Cu}_{2}\left(\mu-\mathrm{L}^{\mathrm{Cl}} \mathrm{O}\right)(\mu-\mathrm{pz})\left(\mathrm{ClO}_{4}\right)\right] \mathrm{ClO}_{4}(2)$. To a hot solution containing 2,6-bis[bis(2-pyridyl-methyl)aminomethyl]-4-chlorophenol $(0.110$

Table 2 Crystallographic data and processing parameters for 1-5 compounds

\begin{tabular}{|c|c|c|c|c|c|}
\hline Compound & 1 & 2 & 3 & $4 \cdot 2 \mathrm{MeCN}$ & $\mathbf{5} \cdot 2 \mathrm{MeCN}$ \\
\hline Empirical formula & $\mathrm{C}_{32} \mathrm{H}_{30} \mathrm{Cl}_{3} \mathrm{Cu}_{2} \mathrm{~N}_{6} \mathrm{O}_{10}$ & $\mathrm{C}_{35} \mathrm{H}_{33} \mathrm{Cl}_{3} \mathrm{Cu}_{2} \mathrm{~N}_{8} \mathrm{O}_{9}$ & $\mathrm{C}_{44} \mathrm{H}_{40} \mathrm{Cl}_{3} \mathrm{Cu}_{2} \mathrm{~N}_{6} \mathrm{O}_{13} \mathrm{P}$ & $\mathrm{C}_{40} \mathrm{H}_{36} \mathrm{ClCu}_{2} \mathrm{~F}_{6} \mathrm{~N}_{14} \mathrm{OP}$ & $\mathrm{C}_{41} \mathrm{H}_{39} \mathrm{Cu}_{2} \mathrm{~F}_{6} \mathrm{~N}_{14} \mathrm{OP}$ \\
\hline Formula mass & 892.07 & 943.14 & 1125.24 & 1036.35 & 1015.93 \\
\hline System & Monoclinic & Monoclinic & Monoclinic & Orthorhombic & Orthorhombic \\
\hline Space group & $P 2_{1} / c$ & $P 2_{1} / c$ & $P 2_{1} / c$ & $\operatorname{Pna2}_{1}$ & $\operatorname{Pna2}_{1}$ \\
\hline$a(\AA)$ & $14.958(3)$ & $16.3363(10)$ & $9.9409(11)$ & $16.2623(7)$ & $16.2326(5)$ \\
\hline$b(\AA)$ & $10.770(2)$ & $10.3267(6)$ & $42.116(5)$ & $12.0018(5)$ & $12.0277(4)$ \\
\hline$c(\AA)$ & $23.043(7)$ & $23.9249(15)$ & $10.8358(10)$ & $21.7768(9)$ & $21.8320(7)$ \\
\hline$\alpha\left(^{\circ}\right)$ & 90 & 90 & 90 & 90 & 90 \\
\hline$\beta\left(\left(^{\circ}\right)\right.$ & $103.386(11)$ & $106.810(2)$ & $103.104(5)$ & 90 & 90 \\
\hline$\gamma\left({ }^{\circ}\right)$ & 90 & 90 & 90 & 90 & 90 \\
\hline$V\left(\AA^{3}\right)$ & $3611.3(15)$ & $3863.7(4)$ & $4418.5(8)$ & $4250.3(3)$ & $4262.5(2)$ \\
\hline$Z$ & 4 & 4 & 4 & 4 & 4 \\
\hline$T(\mathrm{~K})$ & $100(2)$ & $100(2)$ & $100(2)$ & $100(2)$ & $100(2)$ \\
\hline$\mu\left(\mathrm{mm}^{-1}\right)$ & 1.465 & 1.373 & 1.256 & 1.181 & 1.115 \\
\hline$D_{\text {calc }}\left(\mathrm{Mg} \mathrm{m}^{-3}\right)$ & 1.641 & 1.621 & 1.691 & 1.620 & 1.583 \\
\hline Crystal size (mm) & $0.22 \times 0.19 \times 0.13$ & $0.28 \times 0.23 \times 0.17$ & $0.28 \times 0.23 \times 0.17$ & $0.27 \times 0.23 \times 0.12$ & $0.24 \times 0.19 \times 0.17$ \\
\hline$\theta \max \left({ }^{\circ}\right)$ & 25.50 & 26.80 & 25.30 & 26.500 & 29.030 \\
\hline Data collected & 6771 & 40785 & 69771 & 70106 & 55430 \\
\hline Unique refl. $/ R_{\text {int }}$ & $6771 /-$ & $8253 / 0.0435$ & 7989/0.0994 & $8660 / 0.0863$ & 11 115/0.0652 \\
\hline Parameters/restraints & $505 / 6$ & $578 / 0$ & $622 / 0$ & $589 / 1$ & $589 / 1$ \\
\hline Goodness-of-Fit on $F^{2}$ & 1.172 & 1.204 & 1.348 & 1.115 & 0.920 \\
\hline$R_{1} / \mathrm{w} R_{2}$ (all data) & $0.0661 / 0.1957$ & $0.0986 / 0.2343$ & $0.0764 / 0.2165$ & $0.0653 / 0.1893$ & $0.0373 / 0.0775$ \\
\hline Residual extrema $\left(e / \AA^{3}\right)$ & $1.67 /-0.93$ & $1.23 /-1.27$ & $1.46 /-0.78$ & $0.81 /-1.13$ & $0.50 /-0.48$ \\
\hline
\end{tabular}


$\mathrm{g}, 0.20 \mathrm{mmol})$ and $\mathrm{Cu}(\mathrm{ClO})_{2} \cdot 6 \mathrm{H}_{2} \mathrm{O}(0.152 \mathrm{~g}, 0.40 \mathrm{mmol})$ dissolved in $\mathrm{MeOH}(30 \mathrm{~mL})$ pyrazole, $\mathrm{Hpz}(14 \mathrm{mg}, 0.20 \mathrm{mmol})$ was added. The resulting green solution was heated on a steam-bath for $10 \mathrm{~min}$, filtered while hot through celite and then allowed to stand at room temperature. The greenish-blue precipitate which was obtained after few hours was collected by filtration, washed with propan-2-ol and $\mathrm{Et}_{2} \mathrm{O}$ and then dried at room temperature (overall yield: $160 \mathrm{mg}, 85 \%)$. Shiny greenish-blue crystals suitable for X-ray structure determination were obtained from dilute solution. Characterization for 2: calcd for $\mathrm{C}_{35} \mathrm{H}_{33} \mathrm{Cl}_{3} \mathrm{Cu}_{2} \mathrm{~N}_{8} \mathrm{O}_{9} \quad(\mathrm{MM}=$ 943.144 $\mathrm{g} \mathrm{mol}^{-1}$ ): C, 44.57; H, 3.53; N, 11.88\%. Found: C, 44.38; H, 3.59; N, 11.92\%. Selected IR bands $\left(\mathrm{cm}^{-1}\right)$ : 1609 (s), 1485 (w), 1460 (m), 1447 (m), (pyridyl groups); 1120, 1093 (vs.) $\nu_{\text {as }}(\mathrm{Cl}-\mathrm{O})$. UV-VIS spectrum $\left\{\lambda_{\max }, \mathrm{nm}\left(\varepsilon, \mathrm{M}^{-1} \mathrm{~cm}^{-1} / \mathrm{Cu}\right.\right.$ atom $\left.)\right\}$ in $\mathrm{CH}_{3} \mathrm{CN}: 456$ (sh), 799 (194). ESI-MS in $\mathrm{CH}_{3} \mathrm{CN}: \mathrm{m} / z=821.012$, 767.069, 361.035 (major peaks) and for negative ion: $m / z=98.950(100 \%)\left[\mathrm{ClO}_{4}{ }^{-}=\right.$ 99.453]. Molar conductivity, $\Lambda_{\mathrm{M}}\left(\mathrm{CH}_{3} \mathrm{CN}\right)=298 \Omega^{-1} \mathrm{~cm}^{2} \mathrm{~mol}^{-1}$.

$\left[\mathbf{C u}_{2}\left(\mu-\mathrm{L}^{\mathrm{Cl}}-\mathrm{O}\right)\left(\mu-\mathrm{O}_{2} \mathbf{P}\left(\mathbf{O C}_{6} \mathbf{H}_{5}\right)_{2}\right)\right]\left(\mathbf{C l O}_{4}\right)_{2}$ (3). Diphenyl phosphate $(50 \mathrm{mg}, 0.20 \mathrm{mmol})$ which was neutralized with $\mathrm{NaOH}$ ( $0.2 \mathrm{mmol}$ dissolved in $2 \mathrm{~mL} \mathrm{H}_{2} \mathrm{O}$ ) was added dropwise to a warm solution containing 2,6-bis[bis(2-pyridylmethyl) aminomethyl]-4-chlorophenol $(0.110 \mathrm{~g}, \quad 0.20 \mathrm{mmol})$ and $\mathrm{Cu}(\mathrm{ClO})_{2} \cdot 6 \mathrm{H}_{2} \mathrm{O}(0.152 \mathrm{~g}, 0.40 \mathrm{mmol})$ in $\mathrm{MeOH}(20 \mathrm{~mL})$. The resulting green solution was heated on a steam-bath for $10 \mathrm{~min}$, filtered while hot through celite and then allowed to stand at room temperature. The golden single crystals, which separated in the following day, were collected by filtration, washed with propan-2-ol and $\mathrm{Et}_{2} \mathrm{O}$ and then dried at room temperature (overall yield: $203 \mathrm{mg}, 90 \%$ ). Characterization for 3: calcd for $\mathrm{C}_{44} \mathrm{H}_{44} \mathrm{Cl}_{3} \mathrm{Cu}_{2} \mathrm{~N}_{6} \mathrm{O}_{13} \mathrm{P}\left(\mathrm{MM}=1129.272 \mathrm{~g} \mathrm{~mol}^{-1}\right): \mathrm{C}, 46.97 ; \mathrm{H}$, 3.58; N, 7.47\%. Found: C, 47.07; H, 3.73; N, 7.58\%. Selected IR bands $\left(\mathrm{cm}^{-1}\right)$ : $1611(\mathrm{~m}), 1488(\mathrm{~m}), 1448(\mathrm{~m})$ (pyridyl groups); 1121, 1108, 1092 (vs.) $\nu_{\text {as }}(\mathrm{Cl}-\mathrm{O})$. UV-VIS spectrum $\left\{\lambda_{\max }, \operatorname{nm}(\varepsilon\right.$, $\mathrm{M}^{-1} \mathrm{~cm}^{-1} / \mathrm{Cu}$ atom $\left.)\right\}$ in $\mathrm{CH}_{3} \mathrm{CN}$ : $440(542, \mathrm{~b})$. ESI-MS in $\mathrm{CH}_{3} \mathrm{CN}$ : $m / z=835.060,767.074,361.037$ (major peaks) and for negative ion: $m / z=98.949(100 \%)\left[\mathrm{ClO}_{4}{ }^{-}=99.453\right]$. Molar conductivity, $\Lambda_{\mathrm{M}}\left(\mathrm{CH}_{3} \mathrm{CN}\right)=294 \Omega^{-1} \mathrm{~cm}^{2} \mathrm{~mol}^{-1}$.

$\left[\mathrm{Cu}_{2}\left(\mu-\mathrm{L}^{\mathrm{Cl}}-\mathrm{O}\right)(\mathbf{d c a})_{2}\right] \mathbf{P F}_{6} \quad\left(\mathbf{4} \cdot \mathbf{2} \mathbf{C H}_{3} \mathbf{C N}\right)$. To a hot solution containing 2,6-bis[bis(2-pyridylmethyl)aminomethyl]-4-chlorophenol $(0.111 \mathrm{~g}, 0.20 \mathrm{mmol})$ and $\mathrm{Cu}\left(\mathrm{NO}_{3}\right)_{2} \cdot 3 \mathrm{H}_{2} \mathrm{O}(97 \mathrm{mg}$, $0.40 \mathrm{mmol}$ ) in $\mathrm{MeOH}(40 \mathrm{~mL})$ sodium dicyanamide $(36 \mathrm{mg}$, $0.40 \mathrm{mmol}$ ) dissolved in $\mathrm{H}_{2} \mathrm{O}(3 \mathrm{~mL})$ was added dropwise and this was followed by the addition of $\mathrm{NH}_{4} \mathrm{PF}_{6}(100 \mathrm{mg}, 0.6 \mathrm{mmol})$. The resulting greenish-blue solution was heated on a steambath for $10 \mathrm{~min}$, filtered while hot through celite and then allowed to stand at room temperature. The crude precipitate which separated in the following day was collected by filtration and recrystallized from acetonitrile to afford shiny greenishblue single crystals. These were filtered, washed with propan2-ol and $\mathrm{Et}_{2} \mathrm{O}$ and then dried at room temperature (overall yield: $122 \mathrm{mg}, 59 \%$ ). Characterization for $4 \cdot 2 \mathrm{CH}_{3} \mathrm{CN}$ : calcd for $\mathrm{C}_{38} \mathrm{H}_{36} \mathrm{ClCu}_{2} \mathrm{~F}_{6} \mathrm{~N}_{14} \mathrm{OP}\left(\mathrm{MM}=1036.341 \mathrm{~g} \mathrm{~mol}^{-1}\right): \mathrm{C}, 44.04 ; \mathrm{H}$, 3.50; N, 18.92\%. Found: C, 44.48; H, 3.53; N, 18.76\%. Selected IR bands ( $\left.\mathrm{cm}^{-1}\right): 2283(\mathrm{~m}), 2227(\mathrm{~m}), 2161$ (vs.); $1610(\mathrm{~m}) 1574(\mathrm{w})$, 1483 (w), 1445 (m) (pyridyl groups); 837 (s) $\nu(\mathrm{P}-\mathrm{F})$. UV-VIS spectrum $\left\{\lambda_{\max }, \mathrm{nm}\left(\varepsilon, \mathrm{M}^{-1} \mathrm{~cm}^{-1} / \mathrm{Cu}\right.\right.$ atom $\left.)\right\}$ in $\mathrm{CH}_{3} \mathrm{CN}: 457$ (117), 656 (155, b). ESI-MS in $\mathrm{CH}_{3} \mathrm{CN}: m / z=835.060$, 767.071,
361.039 (major peaks) and for negative ion: $\mathrm{m} / \mathrm{z}=144.965$ (100\%). Molar conductivity, $\Lambda_{\mathrm{M}}\left(\mathrm{CH}_{3} \mathrm{CN}\right)=161 \Omega^{-1} \mathrm{~cm}^{2} \mathrm{~mol}^{-1}$.

$\left[\mathbf{C u}_{2}\left(\boldsymbol{\mu}-\mathrm{L}^{\mathrm{Me}}-\mathrm{O}\right)(\mathbf{d c a})_{2}\right] \mathbf{P F}_{6} \cdot \mathbf{2 C H}_{3} \mathbf{C N}\left(\mathbf{5} \cdot \mathbf{2} \mathrm{CH}_{3} \mathbf{C N}\right)$. This complex was prepared using a procedure similar to that described above for $4 \cdot 2 \mathrm{CH}_{3} \mathrm{CN}$ except 2,6-bis[bis(2-pyridylmethyl)aminomethyl]4-methylphenol was used instead of the corresponding 2,6-bis [bis(2-pyridylmethyl)aminomethyl]-4-chlorophenol. Recrystallized of the crude compound from acetonitrile afforded shiny blue well shaped single crystals (overall yield: $144 \mathrm{mg}, 71 \%$ ). Characterization for $5 \cdot 2 \mathrm{CH}_{3} \mathrm{CN}$ : calcd for $\mathrm{C}_{41} \mathrm{H}_{39} \mathrm{Cu}_{2} \mathrm{~F}_{6} \mathrm{~N}_{14} \mathrm{OP}$ $\left(\mathrm{MM}=1015.92 \mathrm{~g} \mathrm{~mol}^{-1}\right): \mathrm{C}, 48.47 ; \mathrm{H}, 3.87 ; \mathrm{N}, 19.30 \%$. Found: C, 48.83; H, 4.00; N, 19.45\%. Selected IR bands $\left(\mathrm{cm}^{-1}\right): 2291(\mathrm{~m})$, 2237 (m), 2173 (vs.), 1637 (m), 1611 (m), 1472 (m), 1446 (m) (pyridyl groups); $844(\mathrm{~s}) \nu(\mathrm{P}-\mathrm{F})$. UV-VIS spectrum $\left\{\lambda_{\max }, \mathrm{nm}(\varepsilon\right.$, $\mathrm{M}^{-1} \mathrm{~cm}^{-1} / \mathrm{Cu}$ atom) $\}$ in $\mathrm{CH}_{3} \mathrm{CN}: 479$ (217), 669 (155, b). ESI-MS in $\mathrm{CH}_{3} \mathrm{CN}: m / z=813.113,747.125,351.063$ (major peaks) and for negative ion: $m / z=144.965(100 \%)\left[\mathrm{PF}_{6}{ }^{-}=144.97\right]$. Molar conductivity, $\Lambda_{\mathrm{M}}\left(\mathrm{CH}_{3} \mathrm{CN}\right)=179 \Omega^{-1} \mathrm{~cm}^{2} \mathrm{~mol}^{-1}$.

\section{Conclusions}

The reaction of copper(II) salts with 2,6-bis[bis(2-pyridylmethyl) aminomethyl]-4-substituted-phenol $\left(\mathrm{L}^{\mathrm{R}}-\mathrm{OH}\right)$ affords two categories of dinuclear complexes in which the phenolate ligand is bridging the two $\mathrm{Cu}(\mathrm{II})$ atoms via the deprotonated phenol group. The first category is the singly bridged $\mu$-phenoxido complexes of the general formula $\left[\mathrm{Cu}_{2}\left(\mu-\mathrm{L}^{\mathrm{R}}-\mathrm{O}\right)(\mathrm{X})_{2}\right]^{+/ 3+}\{\mathrm{R}=\mathrm{Cl}$, $\mathrm{X}=$ dca (complex 4); $\mathrm{R}=\mathrm{X}=\mathrm{Cl}^{-} ;{ }^{1} \mathrm{R}=\mathrm{CH}_{3}, \mathrm{X}=\mathrm{dca}$ (complex 5), $\mathrm{R}=\mathrm{CH}_{3}, \mathrm{X}=\mathrm{OAc}^{-}, \mathrm{Cl}^{-}, \mathrm{N}_{3}{ }^{-}, \mathrm{H}_{2} \mathrm{O}$ and $\left.\mathrm{CH}_{3} \mathrm{CN}\right\} .{ }^{2,4,5,28}$ This class of compounds mediates very weak antiferromagnetic coupling through the bridged phenoxido group. ${ }^{1,2}$ The second category of the bicompartmental phenolate ligands is the doubly bridged complexes where in addition to the bridged phenoxido group, an extra bridge exists and this was observed here in this study in complexes $\left[\mathrm{Cu}_{2}\left(\mu-\mathrm{L}^{\mathrm{R}}-\mathrm{O}\right)(\mu-\mathrm{X})\right]^{+/ 2+}\{\mathbf{1}: \mathrm{X}=$ $\mathrm{OH}^{-}, 2: \mathrm{X}=\mathrm{pz}^{-}$and 3: $\left.\mathrm{X}=\mathrm{O}_{2} \mathrm{P}\left(\mathrm{OC}_{6} \mathrm{H}_{5}\right)_{2}{ }^{-}\right\}$and in some other related complexes 6-9 $\left\{\mathrm{R}=\mathrm{CH}_{3} / t-\mathrm{Bu}, \mathrm{X}=\mathrm{OH}^{-}, \mathrm{OAc}^{-} ; \mathrm{R}=t\right.$-Bu, $\left.\mathrm{X}=\mathrm{OCH}_{3}{ }^{-}\right\} .^{\mathbf{4 , 2 8 , 3 4 , 4 7}}$ In this case moderate ferromagnetic to very strong antiferromagnetic coupling was observed.

The DFT supported analysis of magnetic properties showed that in the case of the doubly bridged complexes 1-3 and 6-9, the key factor determining the nature and strength of the isotropic exchange is the geometry of copper(II) chromophores (SP-SP, SP-TBP or TBP-TBP), thus mutual orientation of magnetic orbitals based on $\mathrm{d}_{x^{2}-y^{2}} / \mathrm{d}_{x^{2}-y^{2}}, \mathrm{~d}_{x^{2}-y^{2}} / \mathrm{d}_{z^{2}}$ or $\mathrm{d}_{z^{2}} / \mathrm{d}_{z^{2}}$ orbitals and efficiency of their magnetic orbital overlaps mediated by both $\mu-\mathrm{L}^{\mathrm{R}}-\mathrm{O}_{\mathrm{ph}}$ and $\mu-\mathrm{X}$ bridging ligands. Therefore, the strongest antiferromagnetic exchange within the studied compounds was found in complexes $3\left(\mathrm{X}=\mathrm{O}_{2} \mathrm{P}\left(\mathrm{OC}_{6} \mathrm{H}_{5}\right)_{2}{ }^{-}\right)$and $7\left(\mathrm{X}=\mathrm{CH}_{3} \mathrm{O}\right)$, where either $\mathrm{d}_{x^{2}-y^{2}} / \mathrm{d}_{x^{2}-y^{2}}$ or $\mathrm{d}_{z^{2}} / \mathrm{d}_{z^{2}}$ orbitals resulting from SP-SP or TBP-TBP copper geometries are efficiently overlapping, whereas the strongest ferromagnetic coupling was induced in the acetato-bridged complex 9. Moreover, the herein the DFT method used based on the B3LYP functional and def2-TZVP(-f) basis set seems to predict properly the nature and strength of the magnetic exchange almost for all the studied complexes, thus enabling us to utilize it also for 
other structurally similar compounds in future. The data in Table 1 revealed that magnetic exchange in the family of doubly hetero-bridged pentacoordinate copper(II) complexes cannot be simply predicted by analyzing the basic structural parameters like $\angle\left(\mathrm{Cu}-\mathrm{O}_{\mathrm{Ph}}-\mathrm{Cu}\right)$ and $\angle(\mathrm{Cu}-\mathrm{X}-\mathrm{Cu})$ angles but the efficiency of magnetic orbitals overlap is more critical in evaluating the variation of copper chromophores geometries (SP vs. TBP) and their mutual orientation.

\section{Acknowledgements}

This research was financially supported by the Department of Chemistry-University of Louisiana at Lafayette. FAM acknowledges support by NAWI Graz. ZT and RH acknowledge support by LO1305.

\section{References}

1 S. S. Massoud, M. Spell, C. Ledet, T. Junk, R. Herchel, R. C. Fischer, Z. Travnicek and F. A. Mautner, Dalton Trans., 2015, 2110.

2 S. S. Massoud, T. Junk, M. Mikuriya, N. Naka and F. A. Mautner, Inorg. Chem. Commun., 2014, 50, 48.

3 (a) J. K. Bjernemose and C. J. McKenzie, Acta Crystallogr., Sect. E: Struct. Rep. Online, 2003, 59, o1275; (b) G. T. Gomes, A. Hazell and C. J. McKenzie, Acta Crystallogr., Sect. C: Cryst. Struct. Commun., 2000, 56, 382.

4 Y. Nishida, H. Shimo, H. Maehara and S. Kida, J. Chem. Soc., Dalton Trans., 1985, 1945.

5 F. Michel, St. P. Torelli, F. Thomas, C. Duboc, C. Philouze, C. Belle, S. Hamman, E. Saint-Aman and J.-L. Pierre, Angew. Chem., Int. Ed., 2005, 44, 438.

6 K. Selmeczi, C. Michel, A. Milet, I. Gautier-Luneau, C. Philouze, J.-L. Pierre, D. Schnieders, A. Rompel and C. Belle, Chem.-Eur. J., 2007, 13, 9093.

7 Y. Gultneh, Y. T. Tesema, T. B. Yisgedu, R. J. Butcher, G. Wang and G. T. Yee, Inorg. Chem., 2006, 45, 3023.

8 B. Das, H. Daver, M. Pyrkosz-Bulska, E. Persch, S. K. Barman, R. Mukherjee, E. Gumienna-Kontecka, M. Jarenmark, F. Himo and E. Nordlander, J. Inorg. Biochem., 2014, 132, 6.

9 M. Jarenmark, M. Haukka, S. Demeshko, F. Tuczek, L. Zuppiroli, F. Meyer and E. Nordlander, Inorg. Chem., 2011, 50, 3866.

10 P. Comba, L. R. Gahan, V. Mereacre, G. R. Hanson, A. K. Powell, G. Schenk and M. Zajaczkowski-Fischer, Inorg. Chem., 2012, 51, 12195.

11 S. Bosch, P. Comba, L. R. Gahan and G. Schenk, Inorg. Chem., 2014, 53, 9036.

12 S. Svane, F. Kryuchkov, C. J. Lennarston, C. J. McKenzie and F. Kjeldsen, Angew. Chem., Int. Ed., 2012, 51, 3216.

13 S. J. Smith, C. J. Noble, R. C. Palmer, G. R. Hanson, G. Schenk, L. R. Gahan and M. J. Riley, JBIC, J. Biol. Inorg. Chem., 2008, 13, 499.

14 S. Blanchard, G. Blain, E. Riviere, M. Nierlich and G. Blondin, Chem.-Eur. J., 2003, 9, 4260.

15 L. M. Berreau, A. Saha and A. M. Arif, Dalton Trans., 2006, 183.
16 S. Halder, S. Dey, C. Rizzoli and P. Roy, Polyhedron, 2014, 78, 85.

17 (a) A. S. Borovik, M. P. Hendrich, T. R. Holman, E. Munck, V. Papaefthymiou and L. Junior Que, J. Am. Chem. Soc., 1990, 112, 6031; (b) A. S. Borovik and L. Junior Que, J. Am. Chem. Soc., 1988, 110, 2345.

18 T. Manago, S. Hayami, H. Oshio, S. Osaka, H. Hasuyama, R. H. Herber, K. J. Berry and Y. Maeda, J. Chem. Soc., Dalton Trans., 1999, 1001.

19 H. Diril, H.-R. Chang, M. J. Nilges, X. Zhang, J. A. Potenza, H. J. Schugar, S. S. Isied and D. N. Hendrickson, J. Am. Chem. Soc., 1989, 111, 5102.

20 R. C. Holz and J. M. Brink, Inorg. Chem., 1994, 33, 4609.

21 (a) K. Matsufuji, H. Shiraishi, Y. Miyasato, T. Shiga, M. Ohba, T. Yokoyama and H. Ōkawa, Bull. Chem. Soc. Jpn., 2005, 78, 851; (b) D. Saravanakumar, N. K. Sengottuvelan, G. Priyadarshni, M. Kandaswamy and H. Ōkawa, Polyhedron, 2004, 23, 665.

22 L. F. Taylor and O. P. Anderson, J. Am. Chem. Soc., 1988, 110, 1986.

23 M. Suzuki, M. Mikuriya, S. Murata, A. Uehara and H. Oshio, Bull. Chem. Soc. Jpn., 1987, 60, 4305.

24 J. J. Maloney, M. Glogowski, D. F. Rohrbach and F. L. Urbach, Inorg. Chim. Acta, 1987, 127, L33.

25 (a) R. K. Edgal, A. D. Bond and C. J. Mckenzie, Dalton Trans., 2009, 3833; (b) R. K. Edgal, F. B. Larsen, A. D. Bond and C. J. Mckenzie, Inorg. Chim. Acta, 2005, 358, 376.

26 T. N. Sorrell, D. L. Jameson and C. J. O'Connor, Inorg. Chem., 1984, 23, 190.

27 A. Biswas, L. K. Das and A. Ghosh, Polyhedron, 2013, 61, 253. 28 S. Torelli, C. Belle, I. Gautier-Luneau, J. L. Pierre, E. SaintAman, J. M. Latour, L. le Pape and D. Luneau, Inorg. Chem., 2000, 39, 3526.

29 N. A. Rey, A. Neves, A. J. Bortoluzzi, C. T. Pich and H. Terenzi, Inorg. Chem., 2007, 46, 348.

30 L. J. Daumann, J. A. Larrabee, P. Comba, G. Schenk and L. R. Gahan, Eur. J. Inorg. Chem., 2013, 3082.

31 T. P. Camargo, F. F. Maia, C. Chaves, B. de Souza, A. J. Bortoluzzi, N. Castilho, T. Bortolotto, H. Terenzi, E. E. Castellano, W. Haase, Z. Tomkowicz, R. A. Peralta and A. Neves, J. Inorg. Biochem., 2015, 146, 77.

32 A. Neves, M. Lanzanaster, A. J. Bortoluzzi, R. A. Peralla, A. Cassellato, E. E. Castellano, P. Herrald, M. J. Riley and G. Schenk, J. Am. Chem. Soc., 2007, 129, 7486.

33 M. Ghiladi, C. J. Mckenzie, A. Meler, A. K. Powell, J. Ulstrup and S. Wocadlo, J. Chem. Soc., Dalton Trans., 1997, 4011.

34 P. Dalgaard, A. Hazell, C. J. McKenzie, B. Moubaraki and K. S. Murray, Polyhedron, 2000, 19, 1909.

35 S. Sarkar, S. Majumder, S. Sasmal, L. Carrella, E. Rentschler and S. Mohanta, Polyhedron, 2013, 50, 270.

36 C. Belle, C. Beguin, I. Gautler-Luneau, S. Hamman, C. Phllouze, J. L. Pierre, F. Thomas, S. Torrelli, S. SaintAman and M. Bonin, Inorg. Chem., 2002, 41, 479.

37 F. B. Johansson, A. D. Bond, U. G. Nilsen, B. Maubaraki, K. S. Murray, K. J. Berry, J. A. Larrabee and C. J. McKenzie, Inorg. Chem., 2008, 47, 5079. 
38 H. Kohler, A. Kolbe and G. Z. Lux, Z. Anorg. Allg. Chem., 1977, 428, 103.

39 (a) S. S. Massoud, A. E. Guilbeau, H. T. Luong, R. Vicente, J. H. Albering, R. C. Fischer and F. A. Mautner, Polyhedron, 2013, 54, 26; (b) S. S. Massoud, M. C. Lemieux, L. L. le Quan, R. Vicente, J. H. Albering and F. A. Mautner, Inorg. Chim. Acta, 2012, 388, 71; (c) F. A. Mautner, J. H. Albering, R. Vicente, F. R. Louka, A. A. Gallo and S. S. Massoud, Inorg. Chim. Acta, 2011, 365, 290; (d) F. A. Mautner, J. B. Soileau, P. K. Bankole, A. A. Gallo and S. S. Massoud, J. Mol. Struct., 2008, 889, 271.

40 (a) S. S. Massoud, R. S. Perkins, F. R. Louka, W. Xu, A. le Roux, Q. Dutercq, R. C. Fischer, F. A. Mautner, M. Handa, Y. Hiraoka, G. L. Kreft, T. Bortolotto and H. Terenzi, Dalton Trans., 2014, 43, 10086; (b) F. R. Louka, A. D. Stewart, E. Regel, F. A. Mautner, S. Demeshko, F. Meyer and S. S. Massoud, Inorg. Chem. Commun., 2012, 22, 60; (c) S. S. Massoud, F. A. Mautner, F. R. Louka, S. Demeshko, S. Dechert and F. Meyer, Inorg. Chim. Acta, 2011, 370, 435.

41 B. J. Hathaway, in Comprehensive Coordination Chemistry, ed. G. Wilkinson, R. D. Gillard and J. A. McCleverty, Pergamon Press, Oxford, England, 1987, vol. 5, p. 533.

42 (a) S. S. Massoud, F. R. Louka, R. N. David, M. J. Dartez, Q. L. Nguyn, N. J. Labry, R. C. Fischer and F. R. Mautner, Polyhedron, 2015, 90, 258; (b) F. A. Mautner, M. Mikuriya, Y. Naka, F. R. Louka and S. S. Massoud, Polyhedron, 2015, 85, 110; (c) S. S. Massoud, L. le Quan, K. Gatterer, J. H. Albering, R. C. Fischer and F. A. Mautner, Polyhedron, 2012, 31, 601; (d) F. A. Mautner, J. H. Albering, E. V. Harrelson, A. A. Gallo and S. S. Massoud, J. Mol. Struct., 2011, 1006, 570; (e) M. Schatz, M. Becker, F. Thaler, F. Hampel, S. Schindler, R. R. Jacobson, Z. Tyeklár, N. N. Murthy, P. Ghosh, Q. Chen, J. Zubieta and K. D. Karlin, Inorg. Chem., 2001, 49, 2312.

43 T. N. Sorrell, Tetrahedron, 1999, 45, 3.

44 l. J. Daumann, P. Comba, J. A. Larrabee, G. Schenk, R. Stranger, G. Cavigliasso and L. R. Gahan, Inorg. Chem., 2013, 52, 2029.

45 A. W. Addison, T. N. Rao, J. Reedijk, J. V. Rijin and G. C. Verschoor, J. Chem. Soc., Dalton Trans., 1984, 1349.
46 R. Boča, A Handbook of Magnetochemical Formulae, Elsevier, Amsterdam, 2012.

47 S. S. Massoud, T. Junk, R. Herchel, Z. Trávníček, M. Mikuriya, R. C. Fischer and F. A. Mautner, Inorg. Chem. Commun., 2015, 60, 1.

48 J. Pasan, F. S. Delgado, Y. Rodriguez-Martin, M. HernandezMolina, C. Ruiz-Perez, J. Sanchiz, F. Lloret and M. Julve, Polyhedron, 2003, 22, 2143.

49 F. Neese, Wiley Interdiscip. Rev.: Comput. Mol. Sci., 2012, 2, 73.

50 (a) C. Lee, W. Yang and R. G. Parr, Phys. Rev. B: Condens. Matter Mater. Phys., 1988, 37, 785; (b) A. D. Becke, J. Chem. Phys., 1993, 98, 1372; (c) A. D. Becke, J. Chem. Phys., 1993, 98, 5648; (d) P. J. Stephens, F. J. Devlin, C. F. Chabalowski and M. J. Frisch, J. Phys. Chem., 1994, 98, 11623.

51 (a) A. Schaefer, H. Horn and R. Ahlrichs, J. Chem. Phys., 1992, 97, 2571; (b) A. Schafer, C. Huber and R. J. Ahlrichs, Chem. Phys., 1994, 100, 5829; (c) F. Weigend and R. Ahlrichs, Phys. Chem. Chem. Phys., 2005, 7, 3297.

52 F. Neese, F. Wennmohs, A. Hansen and U. Becker, Chem. Phys., 2009, 356, 98.

53 (a) E. Ruiz, J. Cano, S. Alvarez and P. Alemany, J. Comput. Chem., 1999, 20, 1391; (b) E. Ruiz, A. Rodríguez-Fortea, J. Cano, S. Alvarez and P. Alemany, J. Comput. Chem., 2003, 24, 982.

54 (a) K. Yamaguchi, Y. Takahara and T. Fueno, in Applied Quantum Chemistry, ed. V. H. Smith, Reidel, Dordrecht, 1986, p. 155; (b) T. Soda, Y. Kitagawa, T. Onishi, Y. Takano, Y. Shigeta, H. Nagao, Y. Yoshioka and K. Yamaguchi, Chem. Phys. Lett., 2000, 319, 223.

$55 \mathrm{~K}$. Momma and F. Izumi, VESTA 3 for three-dimensional visualization of crystal, volumetric and morphology data, $J$. Appl. Crystallogr., 2011, 44, 1272.

56 (a) Bruker, SAINT v. 7.23, Bruker AXS Inc., Madison, Wisconsin, USA, 2005; (b) G. M. Sheldrick, SADABS v. 2, University of Goettingen, Germany, 2001.

57 G. M. Sheldrick, Acta Crystallogr., Sect. A: Found. Crystallogr., 2008, 64, 112.

58 C. F. Macrae, P. R. Edington, P. McCabe, E. Pidcock, G. P. Shields, R. Taylor, T. Towler and J. van de Streek, J. Appl. Crystallogr., 2006, 39, 453. 